\title{
Factors controlling benthic metabolism during low tide along a granulometric gradient in an intertidal bay (Roscoff Aber Bay, France)
}

\author{
Cédric Hubas $^{1,2, *}$, Dominique Davoult ${ }^{2}$, Thierry Cariou $^{3}$, Luis Felipe Artigas ${ }^{1}$ \\ ${ }^{1}$ UMR 8013 ELICO, Université du Littoral Côte d'Opale, MREN, 32 av. Foch 62930 Wimereux, France \\ ${ }^{2}$ UMR 7144 AD2M, and ${ }^{3}$ FR 2424, Université Paris VI, Station Biologique, BP 74, 2968 Roscoff Cedex, France
}

\begin{abstract}
In this study, benthic metabolism was measured during low tide, in a small intertidal bay. Gross primary production (GPP) and benthic community respiration (BCR) were calculated via in situ $\mathrm{CO}_{2}$ flux measurements at the air-sediment interface within a benthic chamber. These rates (GPP and BCR) were determined simultaneously with microphytobenthos (MPB), bacterial (BB), macrofaunal $(\mathrm{MaB})$ and meiofaunal $(\mathrm{MeB})$ biomasses, grain size analysis and nutrient standing stocks in sediment porewater $\left(\mathrm{NO}_{2}{ }^{-}, \mathrm{NO}_{3}{ }^{-}, \mathrm{NH}_{4}{ }^{+}, \mathrm{SiO}_{3}{ }^{2-}\right.$ and $\left.\mathrm{PO}_{4}{ }^{3-}\right)$. The aims of this study were to determine (1) the relative influence of environmental regulating factors on benthic metabolism under in situ conditions and (2) the relative contribution of benthic compartments to BCR. Among all the potential regulating factors measured (i.e. sediment temperature, dissolved inorganic nutrient concentrations in porewater), and the entire size range of benthic organisms sampled (i.e. from macrofauna to bacteria), results showed that (1) granulometry strongly controlled the distribution of benthic compartments at the bay scale and (2) GPP and BCR were mostly influenced by temperature at the sampling site scale. Moreover, out of bacteria, macrofauna and meiofauna, bacterial activity contributed the most to $\mathrm{BCR}$ (bacterial > macrofaunal > meiofaunal respiration). Mean bacterial respiration was estimated to be $1.5 \pm 0.5 \mathrm{mgC} \mathrm{m}^{-2} \mathrm{~h}^{-1}$ and represented up to $88 \%$ of $\mathrm{BCR}$ in fine-sand sediments.
\end{abstract}

KEY WORDS: In situ measurements · Benthic primary production · Respiration · Microphytobenthos · Bacteria $\cdot$ Temperature $\cdot$ Nutrients

\section{INTRODUCTION}

Over the past decades, gross primary production (GPP) and benthic community respiration (BCR) of intertidal sediments have been studied extensively. Indeed, intertidal sediments play an important role in the production and remineralization of organic matter.

Microphytobenthos (MPB) production is primarily controlled by light availability (Parsons et al. 1984). However, a wide range of factors are known to significantly affect MPB biomass and production. Some studies have focused on the particular influence of sediment dynamics (Yin \& Harrison 2000, Perkins et al.
2003), erosion (Delgado et al. 1991, de Jonge \& van Beusekom 1992, de Jonge \& van Beusekom 1995), temperature (Rasmussen et al. 1983, Blanchard et al. 1996, Hancke \& Glud 2004), nutrient availability (Underwood \& Provot 2000, Thornton et al. 2002, Welker et al. 2002, Saburova \& Polikarpov 2003), meiofauna/macrofauna feeding activity (Riera et al. 1996, Epstein 1997a,b, Blanchard et al. 2000, Hagerthey et al. 2002, Pinckney et al. 2003), and bioturbation (Hansen \& Kristensen 1997, Goñi-Urriza et al. 1999, Pinckney et al. 2003). However, predominant regulating factors need to be realized at the ecosystem level in order to draw predictive models. Moreover, through detrital path- 


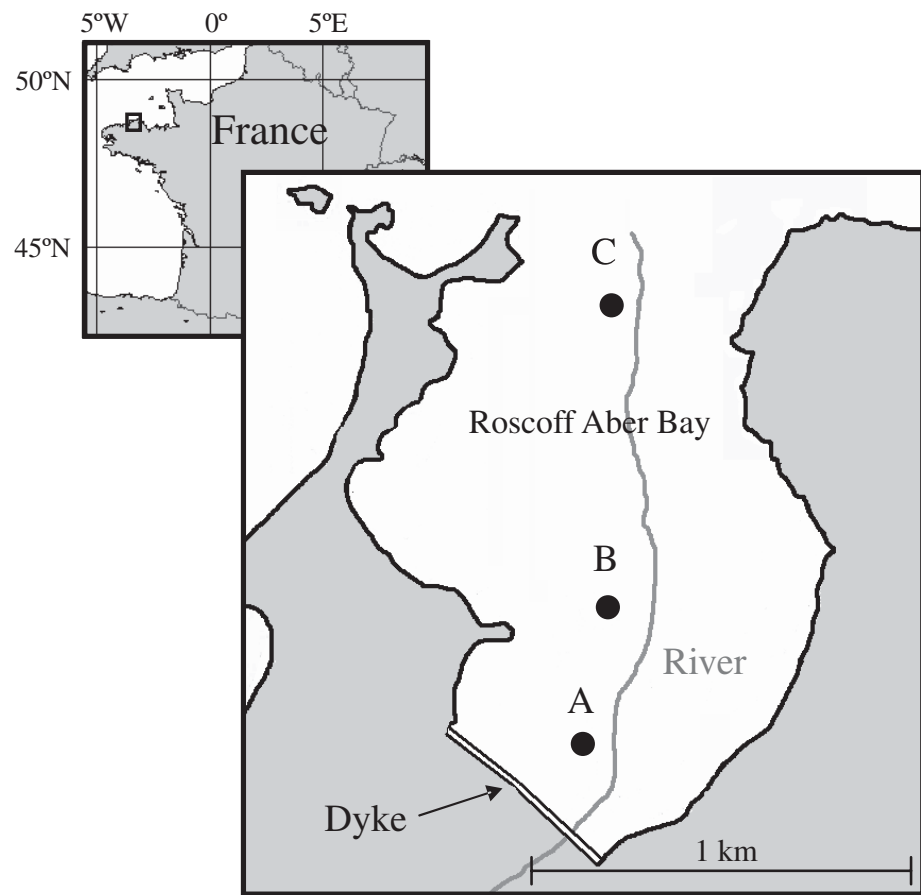

Fig. 1. Location of the sampling stations in the Roscoff Aber Bay (France)

ways, bacterial remineralization and production generally represent the main fate of intertidal MPB carbon (Middelburg et al. 2000). However, despite some strong assumptions, and with respect to other benthic compartments, there is a lack of evidence showing that bacterial heterotrophic activity is contributing significantly to BCR. Indeed, no study has yet quantified all heterotrophic and autotrophic components simultaneously with $\mathrm{BCR}$ rates.

The aims of this study were (1) to determine, among the putative regulating factors (i.e. sediment temperature, dissolved inorganic nutrients concentrations in porewater), the primarily regulating factors of primary production in intertidal ecosystems during low tide and (2) to test, among the entire size range of benthic organisms (i.e. from macrofauna to bacteria), the hypothesis that among macrofauna and meiofauna, bacterial respiration is the highest contributor to benthic community respiration (BCR).

\section{MATERIALS AND METHODS}

In this study, GPP and BCR were measured in a small intertidal bay (ca. $2 \mathrm{~km}^{2}$ ), from February 2003 to February 2004, simultaneously with $\mathrm{NO}_{3}^{-}, \mathrm{NO}_{2}^{-}, \mathrm{NH}_{4}{ }^{+}$, $\mathrm{SiO}_{3}{ }^{2-}$ and $\mathrm{PO}_{4}{ }^{3-}$ concentrations in porewater, sediment grain size was analysed, sediment temperature and macro-, meio- and microbenthic (MPB and bacteria) biomass were also quantified.
Sampling area. The Roscoff Aber Bay (Fig. 1) is a small intertidal bay (about $1 \mathrm{~km}$ wide and $2 \mathrm{~km}$ long), entirely located above mid-tide level (Chauris 1988), which allowed for measurements both at a microscale and at the bay scale. This site includes different types of intertidal sediments (Rullier 1959) and represents a complex ecosystem. In the southern part, a locked gate in a dyke allows small river inputs. Three sampling stations corresponding to 3 different intertidal sediments, representative of the entire bay, were studied during emersed periods. Sampling sites were selected along a granulometric gradient. The 'river station' (Stn A: $48^{\circ} 42.821^{\prime} \mathrm{N}, 4^{\circ} 00.050^{\prime} \mathrm{W}$ ) was located at the river mouth (southern part of the bay) and corresponded to the finest sediments. The 'Lagadennou station' (Stn B: $48^{\circ} 42.996^{\prime} \mathrm{N}, 3^{\circ} 59.933^{\prime} \mathrm{W}$ ) was located in the middle of the bay and corresponded to sandy sediments. The 'Roch Kroum station' (Stn C: $48^{\circ} 43.444^{\prime} \mathrm{N}$, $3^{\circ} 59.765^{\prime} \mathrm{W}$ ) was the coarsest sampling site, located at the entrance of the bay (around mid-tide level).

$\mathbf{C O}_{2}$ fluxes. $\mathrm{CO}_{2}$ fluxes at the air-sediment interface were measured in situ within a benthic chamber (Migné et al. 2002), functioning with a closed circuit of $\mathrm{CO}_{2}$ analysis. This original method allowed measurements of oxic and anoxic respiration. Both were measured during dark incubations, providing a measure of decomposition that is not affected by terminal electron acceptors. Indeed, benthic metabolism is traditionally measured by sediment $\mathrm{O}_{2}$ exchanges, which could lead to an underestimate of benthic respiration. Oxygen-based measurements could leave out decomposition processes occurring during anaerobic respiration if a lag time exists between the production of reduced compounds and their reoxidation (Pickney et al. 2003). Briefly, a $0.071 \mathrm{~m}^{2}$ sediment area $(10 \mathrm{~cm}$ depth) was enclosed and changes in air $\mathrm{CO}_{2}$ concentration (ppm) were measured with a $\mathrm{CO}_{2}$ infrared gas analyser (LiCor Li 800). Incident photosynthetically active radiation (400-700 nm, PAR in $\mu$ mol quanta $\mathrm{m}^{-2} \mathrm{~s}^{-1}$ ) was also measured inside the benthic chamber with a LiCor quantum sensor. Data were recorded with a data logger (LiCor Li-1400) with a $30 \mathrm{~s}$ logging frequency. $\mathrm{CO}_{2}$ fluxes were then calculated from recorded data of both light and dark incubation using the slope of $\mathrm{CO}_{2}$ con-

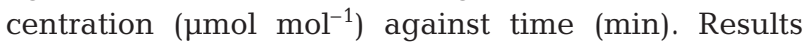
were then expressed in carbon unit for the bulk benthic community (mg $\mathrm{C} \mathrm{m}^{-2} \mathrm{~h}^{-1}$ ) assuming a molar volume of $22.4 \mathrm{l} \mathrm{mol}^{-1}$ at standard temperature and pressure (STP) and a molar mass of $12 \mathrm{~g} \mathrm{~mol}^{-1}$ for $\mathrm{CO}_{2}$. Measurements were assessed at ambient light and in darkness in order to estimate respectively, net benthic primary production (NPP) and benthic community respiration (BCR). Benthic gross primary production (GPP) was then calculated from NPP and BCR measurements $(\mathrm{GPP}=\mathrm{NPP}+\mathrm{BCR})$. 
Environmental measurements. Sediment porewater was sampled beside the benthic chamber (triplicates) at Stns A, B and C (5.4 cm inner diameter, $5 \mathrm{~cm}$ depth) and stored in a cool box until returned to the laboratory. Nutrients concentrations were then measured with a Technicon autoanalyser (Treguer \& Le Corre 1975). Briefly, for nitrite $\left(\mathrm{NO}_{2}{ }^{-}\right)$, nitrate $\left(\mathrm{NO}_{3}{ }^{-}\right)$, reactive silicate $\left(\mathrm{SiO}_{3}{ }^{2-}\right)$ and ortho-phosphate, measurements were automatically assessed by colorimetry (respectively according to Bendschneider \& Robinson 1952, Murphy \& Riley 1962, Wood et al. 1967, Strickland \& Parsons 1972). Ammonia $\left(\mathrm{NH}_{4}^{+}\right)$concentrations were measured manually by colorimetry (Koroleff 1969).

The sediment grain size analysis was assessed for each sampling site. Sediment was also sampled $(5 \mathrm{~cm}$ depth) beside the benthic chamber, rinsed with freshwater and dried at $100^{\circ} \mathrm{C}$ for $48 \mathrm{~h}$. Grain size analysis was then assessed by standard sieve fractionation (Folk 1980, Holme \& McIntyre 1984, the finest sieve used was $63 \mu \mathrm{m})$.

Temperature was measured every $20 \mathrm{~min}$ in the superficial layer of the sediment next to the benthic chamber during $\mathrm{CO}_{2}$ flux measurements with a pocket digital thermometer $\left( \pm 0.1^{\circ} \mathrm{C}\right)$.

Chlorophyll a concentration. Since Roscoff sediments were not cohesive, the top 2 to $3 \mathrm{~mm}$ of sediment were sampled (triplicates) inside the benthic chamber area after the incubation period, using a $1.6 \mathrm{~cm}$ inner diameter cut-off syringe with a piston. The core was simply sliced in the field, stored in a cool box until returned to the laboratory where it was then stored at $-32^{\circ} \mathrm{C}$ until analysis. The sample was defrosted in the dark, and $5 \mathrm{ml}$ of $90 \%$ acetone was added. Samples were gently mixed and stored at $4^{\circ} \mathrm{C}$ for $4 \mathrm{~h}$. After Chl a extraction, the sample was centrifuged $(800 \times g$, $3 \mathrm{~min})$. The supernatant was removed and Chl a concentrations were measured by fluorimetry (Yentsch \& Menzel 1963) with a Turner designs 10 AU chlorophyll fluorometer (excitation filter 430-450 nm, emission filter 650-680 nm). Fluorescence was measured and Chl a concentration was calculated according to Lorenzen (1966).

Bacterial biomass. At each sampling site, from February 2003 to February 2004, cores $(1.6 \mathrm{~cm}$ inner diameter, $1 \mathrm{~cm}$ depth) were collected with a cut off alcohol cleaned syringe (triplicates) inside the benthic chamber area. Samples were immediately fixed in a $20 \mathrm{ml}$ formaldehyde solution (final concentration 2 to $3 \%$ ), diluted with filtered sea water $(0.22 \mu \mathrm{m})$ and saturated with sodium tetraborate. Bacterial communities were then extracted from sediment by (1) vortex agitation which allowed homogeneous subsampling of $5 \mathrm{ml}$ of the sediment slurry, and (2) addition of $150 \mu \mathrm{l}$ of polyoxyethylene sorbitan monoleate (Tween 80, Chevaldonné \& Godfroy 1997), followed by sonication
(35 kHz, $5 \mathrm{~min})$. The samples were centrifuged $(1750 \times$ $g, 10 \mathrm{~min}, 4^{\circ} \mathrm{C}$ ), and $1 \mathrm{ml}$ subsamples were stained with 4', 6'-diamidino-2-phenylindole (DAPI, $2 \mu \mathrm{g} \mathrm{ml}^{-1}$ ). Sediment was incubated for 15 min with DAPI in the dark at $4^{\circ} \mathrm{C}$, and filtered on a black polycarbonate membrane filter (GTBP Millipore, $0.2 \mu \mathrm{m}$ ) under low pressure $(<10 \mathrm{kPa})$. Bacteria were counted by epifluorescence microscopy (Leica, equipped with a $365 \mathrm{~nm}$ filter) under non-fluorescent oil immersion, 10 randomly selected fields $(0.1 \times 0.1 \mu \mathrm{m})$ were observed for determination of bacterial abundance. Bacterial carbon biomass was estimated with a conversion factor of $20 \mathrm{fgC} \mathrm{cell}^{-1}$ (Cho \& Azam 1990, Delmas et al. 1992, Raghukumar et al. 2001).

Meiofauna and macrofauna biomass. Meiofauna was sampled with a $50 \mathrm{ml}$ tube $(2.9 \mathrm{~cm}$ inner diameter, $2 \mathrm{~cm}$ depth; Coull \& Bell 1979) next to the benthic chamber, returned to the laboratory, killed with $10 \%$ formaldehyde solution, saturated with sodium tetraborate and stored until analysis. Meiofauna was then extracted from the sediment using colloidal silica soil Ludox $^{\mathrm{TM}}$ HS-40 (de Jonge \& Bouwman 1977) as described by Burgess (2001). Taxonomic diversity was estimated (organisms were stained with Rose Bengal) and meiofauna carbon biomass was then estimated. An average biomass of $1 \mu \mathrm{C}$ ind $^{-1}$. (Manini et al. 2003) was used. Macrofauna inhabiting the entire benthic chamber surface area was sampled $\left(0.071 \mathrm{~m}^{2}, 10 \mathrm{~cm}\right.$ depth), directly sieved $(1 \mathrm{~mm})$ in the field, and returned to the laboratory. Macrofauna was then killed with $10 \%$ formaldehyde solution, saturated with sodium tetraborate and stored until analysis. The biggest organisms were directly separated from sediment while smaller ones were first detected with Rose Bengal coloration. Macrofauna was then identified and counted and species diversity was estimated. Ash-free dry weight (AFDW) biomass was measured. Organisms were dried at $100^{\circ} \mathrm{C}$ for $24 \mathrm{~h}$, weighted $( \pm 0.01 \mathrm{mg})$, burned at $550^{\circ} \mathrm{C}$ for $4 \mathrm{~h}$, after which the ashes were weighed ( $\pm 0.01 \mathrm{mg})$.

Statistics. Non-linear regressions: Temporal variabilities of BB, BCR, GPP, and specific primary production ( $\mathrm{SPP}, \mathrm{mg} \mathrm{C} \mathrm{mg} \mathrm{Chl} \mathrm{a}^{-1} \mathrm{~h}^{-1}$ ) were fitted with sinusoidal curves, using the SPSS Systat $9^{\odot}$ software.

A wide range of mathematical models from powerlaw/exponential growth curves (Thamdrup \& Fleischer 1998, Epping \& Kühl 2000, Wieland \& Kühl 2000, Hancke \& Glud 2004) to more sophisticated equations involving cardinal temperature criteria (Rosso et al. 1995, Blanchard et al. 1996) can be used to describe temperature influence on benthic metabolism. Temperature influence was thus first tested with an exponential curve (Arrhenius plot) according to Hancke \& Glud (2004) using the SPSS Systat $9^{\odot}$ software: 


$$
\begin{aligned}
& \mathrm{BCR}=A_{1} \exp \left(-E_{\mathrm{a} 1} / R \mathrm{~T}\right) \\
& \mathrm{GPP}=A_{2} \exp \left(-E_{\mathrm{a} 2} / R \mathrm{~T}\right)
\end{aligned}
$$

where GPP and BCR have units of $\mathrm{mg} \mathrm{C} \mathrm{m}^{-2} \mathrm{~h}^{-1}, A_{\mathrm{i}}$ is a pre-exponential factor, $E_{\mathrm{ai}}$ is the community response of GPP and BCR to temperature (apparent activation energy in $\left.\mathrm{J} \mathrm{mol}^{-1}\right), R$ is the gas constant $\left(8.3144 \mathrm{~J} \mathrm{~K}^{-1}\right.$ $\mathrm{mol}^{-1}$ ) and $\mathrm{T}$ the absolute temperature $(\mathrm{K})$.

However, since GPP against temperature expresses a classical metabolic-temperature response at Stn A (i.e. an increase of GPP until an optimal temperature and then a decrease), a short-term temperature influence model (Eq. 2, Blanchard et al. 1996: cardinal temperature model) was fitted to GPP at this sampling site with the Statsoft, Statistica 6.1 software:

$$
\operatorname{GPP}=\operatorname{GPP}_{\max }\left(\frac{\mathrm{T}_{\max }-\mathrm{T}}{\mathrm{T}_{\max }-\mathrm{T}_{\mathrm{opt}}}\right)^{\beta} \exp \left[-\beta\left(\frac{\mathrm{T}_{\max }-\mathrm{T}}{\mathrm{T}_{\max }-\mathrm{T}_{\mathrm{opt}}}-1\right)\right]
$$

where $\mathrm{GPP}_{\max }$ represented maximum GPP, T is temperature $\left({ }^{\circ} \mathrm{C}\right), \mathrm{T}_{\mathrm{opt}}$ is optimal temperature (i.e. corresponded to the maximum of GPP), $\mathrm{T}_{\max }$ is maximum temperature supported by primary producers (i.e. beyond $\mathrm{T}_{\text {opt }}$ GPP decreases to reach the zero value at $\mathrm{T}_{\max }$ ), and $\beta$ is a dimensionless adjustment parameter. This allowed the use of cardinal temperature criteria to describe metabolic activity. The following criteria were used for categorization: psychrophiles $\mathrm{T}_{\text {opt }} \leq 15^{\circ} \mathrm{C}$ and $\mathrm{T}_{\text {max }} \leq 35^{\circ} \mathrm{C}$, psychrotrophs $\mathrm{T}_{\mathrm{opt}} \leq 25^{\circ} \mathrm{C}$ and $\mathrm{T}_{\max } \leq 35^{\circ} \mathrm{C}$, and mesophiles $\mathrm{T}_{\text {opt }} \sim 25$ to $40^{\circ} \mathrm{C}$ and $\mathrm{T}_{\text {max }} \approx 35$ to $45^{\circ} \mathrm{C}$ (Isaksen \& Jørgensen 1996, Hancke \& Glud 2004).

The $Q_{10}$ value was calculated directly from the nonlinear regressions of Eqs. (1), (2), \& (3) using a temperature interval from 10 to $20^{\circ} \mathrm{C}$ :

$$
\begin{aligned}
Q_{10}(\mathrm{BCR}) & =\mathrm{BCR}_{20^{\circ} \mathrm{C}} / \mathrm{BCR}_{10^{\circ} \mathrm{C}} \\
Q_{10}(\mathrm{GPP}) & =\mathrm{GPP}_{20^{\circ} \mathrm{C}} / \mathrm{GPP}_{10^{\circ} \mathrm{C}}
\end{aligned}
$$

Multivariate analysis: In order to point out the environmental gradient influence, PCA was calculated with the software StatBox V6.1 ${ }^{\odot}$ using GPP, BCR, SPP, $\mathrm{T}^{\circ} \mathrm{C}$, median grain size, nutrients, Chl $a$, meiofauna $(\mathrm{MeB})$, macrofauna $(\mathrm{MaB})$ and bacterial (BB) biomass at all sampling occasions, at Stns A, B and C simultaneously. For all the sampling occasions, the name of the station and the date (number of the month) were reported (e.g. $A_{2}$ for Stn $A$ in February, $A_{2}{ }^{\prime}$ when 2 samples were assessed in the same month).

According to van Es (1982), the contribution of dissolved inorganic nitrogen (DIN), silicate (DISi) and phosphate (DIP) to GPP was tested using a multiple linear regression with the software StatBox V6.1 ${ }^{\odot}$. The contribution of $\mathrm{BB}, \mathrm{MaB}, \mathrm{MeB}$ and $\mathrm{Chl} a$ to $\mathrm{BCR}$ was also tested:

$$
\mathrm{BCR}=C_{1} \mathrm{MaB}+C_{2} \mathrm{MeB}+C_{3} \mathrm{BB}+C_{4} \mathrm{Chl} a+C_{s 1}(6)
$$

$$
\mathrm{GPP}=C_{5} \mathrm{DIN}+C_{6} \mathrm{DISi}+C_{7} \mathrm{DIP}+C_{s 2}
$$

where $C_{i}$ represents the variables coefficients and $C_{s i}$ represents the constant. Variable coefficients indicated, on the one hand, DIN, DISi, and DIP partial contributions to GPP and, on the other hand, BB, MaB, $\mathrm{MeB}$ and $\mathrm{Chl}$ a partial contributions to BCR. Standardized coefficients (mean weight-normalized data) and the probability associated to each variable coefficient (Student $t$-test) were also calculated. The best fit of variables, which both maximized the proportion of the variability explained by the model and minimized the number of variables used for the regression, was estimated.

\section{RESULTS}

\section{Environmental gradient}

The median grain size $( \pm \mathrm{SD})$ of each sampling site was calculated for the entire year and described by the Wentworth scale (Holme \& McIntyre 1984): Stn A corresponded to very fine-sand sediments $(132 \pm 54 \mu \mathrm{m})$, Stn B to fine-sand sediments $(215 \pm 43 \mu \mathrm{m})$ and Stn C to medium-sand sediments $(251 \pm 10 \mu \mathrm{m})$. In order to improve the reading of the paper, Stns A, B and C will be described, respectively, as containing muddy (15 \pm $8 \%$ mud), sandy and coarse sediments.

Results showed a nutrient concentration gradient with the higher concentrations in the muddiest sediments. Moreover, at all sampling sites $\mathrm{NH}_{4}{ }^{+}$and $\mathrm{SiO}_{3}{ }^{2-}$ porewater concentrations were higher than $\mathrm{NO}_{2}^{-}$, $\mathrm{NO}_{3}{ }^{-}$and $\mathrm{PO}_{4}{ }^{3-}$ concentrations (Fig. 2). Mean porewater nitrite and nitrate concentrations at Stns A, B and $\mathrm{C}$ were respectively $1.8 \pm 2.7,0.4 \pm 0.5$ and $0.2 \pm$ $0.2 \mu \mathrm{M}$ for $\mathrm{NO}_{2}^{-}$and $10.0 \pm 13.0,6.5 \pm 7.6$ and $4.1 \pm 3.9$ $\mu \mathrm{M}$ for $\mathrm{NO}_{3}{ }^{-}$. $\mathrm{NO}_{2}{ }^{-}$represented, respectively, $1.4,0.8$ and $0.9 \%$ and $\mathrm{NO}_{3}{ }^{-}$represented $7.7,12.5$ and $21.1 \%$ of total DIN. Consequently, nitrite and nitrate were grouped and expressed as nitrite + nitrate $\left(\mathrm{NO}_{\mathrm{x}}\right)$. The relative importance of $\mathrm{NO}_{\mathrm{x}}$ (and particularly nitrate) increased with increasing sediment grain size. Moreover, $\mathrm{NH}_{4}{ }^{+}$and $\mathrm{SiO}_{3}{ }^{2-}$ (Fig. 2a,b) seemed to be coupled and showed similar patterns, with maximum values occurring in spring and late autumn, while $\mathrm{NO}_{\mathrm{x}}$ and $\mathrm{PO}_{4}{ }^{3-}$ (Fig. 2C,d) showed maximum values in winter and summer.

PCA was calculated grouping GPP, BCR, SPP, $\mathrm{T}^{\circ} \mathrm{C}$, median grain size, nutrients, $\mathrm{Chl} a$, meiofauna (MeB), macrofauna $(\mathrm{MaB})$ and bacterial $(\mathrm{BB})$ biomass of the 3 sampling sites (Fig. 3a,b). Rows containing missing data were systematically deleted. The F1 and F2 axes together explained up to $71 \%$ of the total variability. Along the $\mathrm{F} 1$ axis ( $51 \%$ of the total variability) median 

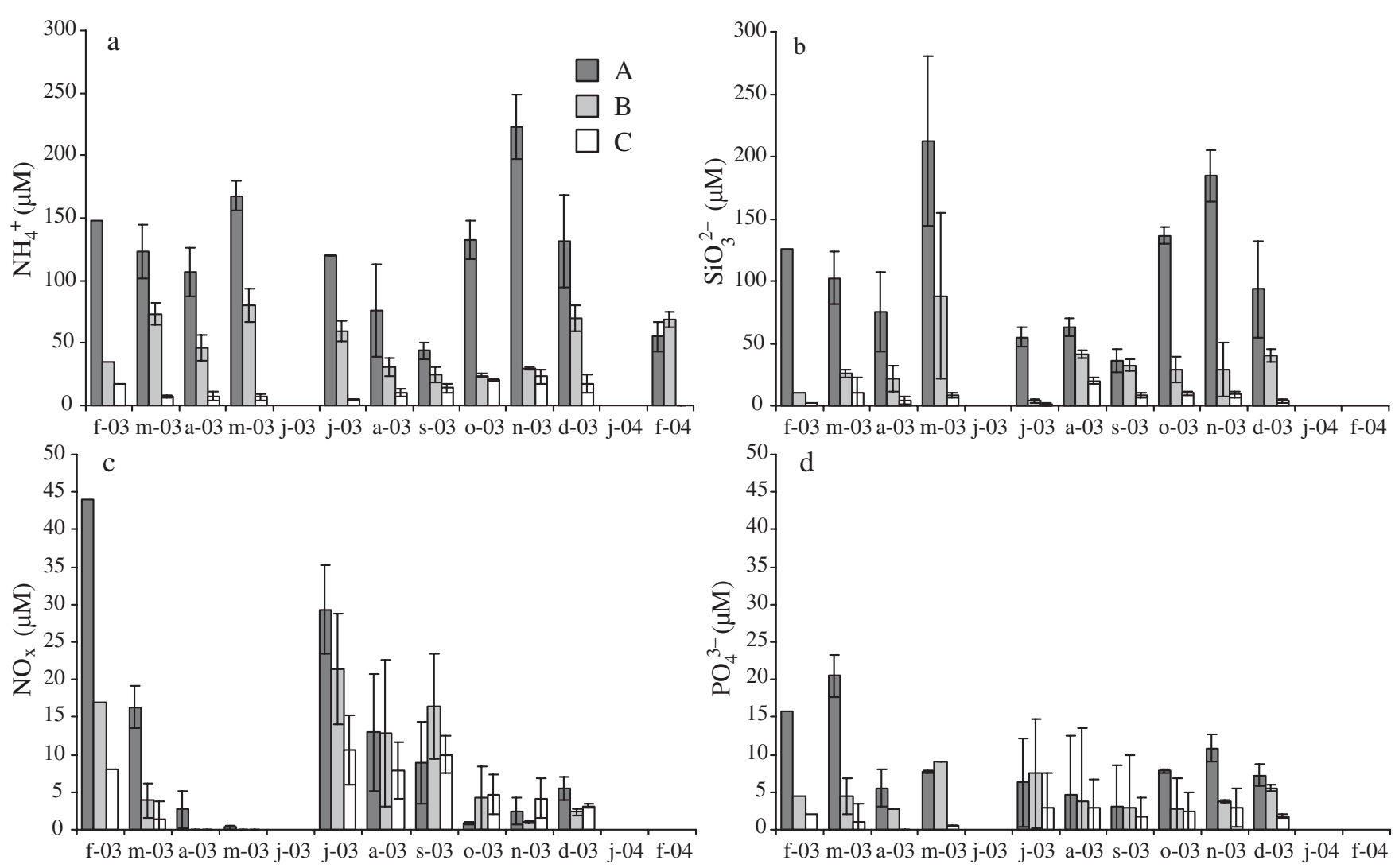

Fig. 2. Nutrient concentrations $\left(\mu \mathrm{mol}^{-1}\right.$ ) in sediment porewater in muddy (A), sandy (B) and coarse sediments (C), error bars indicate spatial variability (triplicates). (a) $\mathrm{NH}_{4}{ }^{+}$concentration, (b) $\mathrm{SiO}_{3}{ }^{2-}$ concentration, (c) $\mathrm{NO}_{\mathrm{x}}$ concentration and (d) $\mathrm{PO}_{4}{ }^{3-}$ concentration. $x$-axis labels are month-year of sample

grain size was negatively correlated to a group of standing stock variables: nutrients (Pearson correlations: $\mathrm{r}=-0.91,-0.83$ and -0.82 , for $\mathrm{NH}_{4}{ }^{+}, \mathrm{SiO}_{3}{ }^{2-}$ and $\mathrm{PO}_{4}{ }^{3-}$, respectively, for all $\mathrm{n}=31, \mathrm{p}<0.001$ ) and benthic compartments biomass $(\mathrm{r}=-0.60,-0.83,-0.66$ and -0.61 for $\mathrm{BB}, \mathrm{MaB}, \mathrm{MeB}$ and $\mathrm{Chl}$ a, respectively, for all $n=31, p<0.001)$. Along the F2 axis $(20 \%$ of the total variability) temperature was positively correlated only with benthic fluxes $(\mathrm{r}=0.49, \mathrm{n}=31, \mathrm{p}<$ 0.01 for BCR, $\mathrm{r}=0.42, \mathrm{n}=31, \mathrm{p}<0.05$ for GPP and $\mathrm{r}=$ $0.50, \mathrm{n}=31, \mathrm{p}<0.01$ for SPP). Median grain size, $\mathrm{NH}_{4}{ }^{+}, \mathrm{SiO}_{3}{ }^{2-}, \mathrm{PO}_{4}{ }^{3-}, \mathrm{BB}, \mathrm{MeB}, \mathrm{MaB}$ and $\mathrm{Chl} a$ were mostly contributing to F1 (respectively, 12, 13, 13, 9, 9, 10,12 and $10 \%$ ) while $\mathrm{T}^{\circ} \mathrm{C}, \mathrm{BCR}$, GPP and SPP were mostly contributing to F2 (respectively 26, 15, 22 and $21 \%)$. Sampling sites were well separated and were distributed along the F1 axis (Fig. 3b, with finest sediments at the right end of the graph and coarsest sediments at the left). Within each of the sampling sites, sampling period (i.e. $A_{2}$ to $A_{11}, B_{3}$ to $B_{12}$ and $C_{2}$ to $C_{12}$ for Stns $A, B$ and $C$, respectively) showed a high variability and were distributed along the F2 axis (with summer values at the upper end of the graph and winter values at the bottom).

\section{Benthic metabolism}

GPP ranged from 7.2 to $30.2,7.6$ to 27.7 and 3.6 to $12.5 \mathrm{mg} \mathrm{C} \mathrm{m}^{-2} \mathrm{~h}^{-1}$ at Stns A, B and C, respectively. GPP rates were significantly different between the 3 sampling sites (Kruskal-Wallis, $\mathrm{p}<0.01$ ) being higher at Stn A $\left(15.3 \pm 7.4 \mathrm{mgC} \mathrm{m}^{-2} \mathrm{~h}^{-1}\right)$ and B $(16.9 \pm 7.0 \mathrm{mgC}$ $\left.\mathrm{m}^{-2} \mathrm{~h}^{-1}\right)$ than at Stn $\mathrm{C}\left(7.2 \pm 2.6 \mathrm{mgC} \mathrm{m}^{-2} \mathrm{~h}^{-1}\right)$. GPP showed a seasonal pattern (Fig. 4) and was fitted with a sinusoidal curve at the 3 sampling sites:

$$
\begin{aligned}
& \text { Stn } A_{i} \text { GPP }=16.06+8.08 \sin [(2 \pi / 365) d+10.44] \\
& \left(\mathrm{R}^{2}=0.931, \mathrm{n}=16\right) \\
& \operatorname{Stn} B_{;} \text {GPP }=17.74+7.74 \sin [(2 \pi / 365) d+10.00] \\
& \left(\mathrm{R}^{2}=0.950, \mathrm{n}=15\right) \\
& \text { Stn } C_{i} \text { GPP }=7.68+2.67 \sin [(2 \pi / 365) d+9.77] \\
& \left(\mathrm{R}^{2}=0.955, \mathrm{n}=16\right)
\end{aligned}
$$

where $d=$ the day number. Maximum values occurred in summer $\left(24.1,25.5\right.$ and $10.3 \mathrm{mg} \mathrm{C} \mathrm{m}^{-2} \mathrm{~h}^{-1}$ respectively on, 8 August, 28 August, and 11 September, for Stns A, B and C).

Specific primary production (SPP in $\mathrm{mg} \mathrm{C} \mathrm{mg} \mathrm{Chl} \mathrm{a}^{-1}$ $\mathrm{h}^{-1}, \mathrm{P}: \mathrm{B}$ ratio) clearly showed a seasonal pattern 
(Fig. 5). SPP was fitted with a sinusoidal model at the 3 sampling sites:

Stn $A_{i} \operatorname{SPP}=0.49-0.28 \sin [(2 \pi / 365) d+1.44]$

$$
\left(\mathrm{R}^{2}=0.922, \mathrm{n}=16\right)
$$

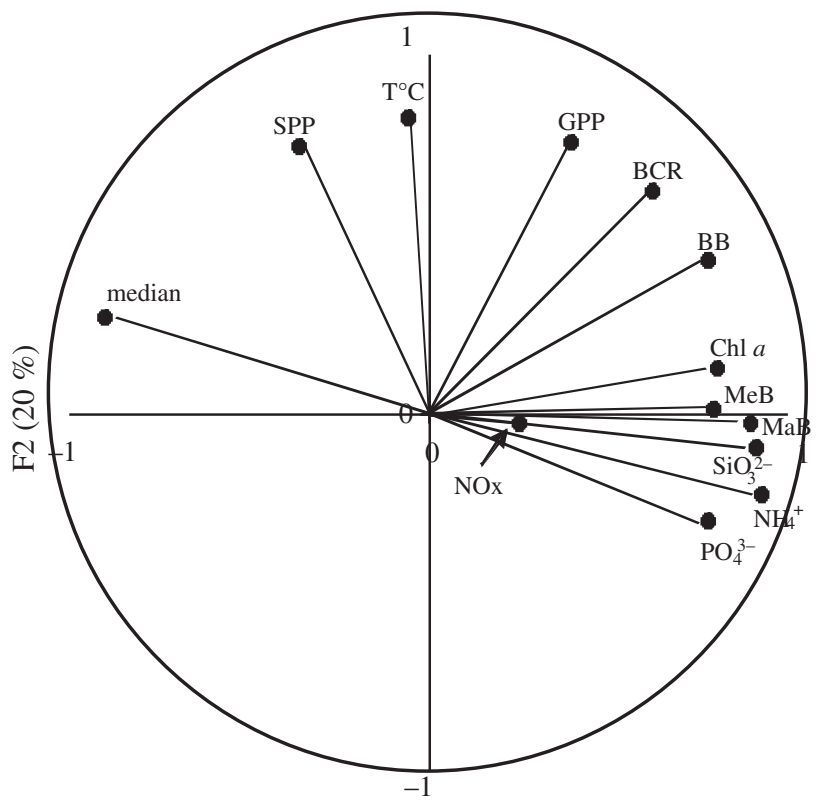

F1 $(51 \%)$

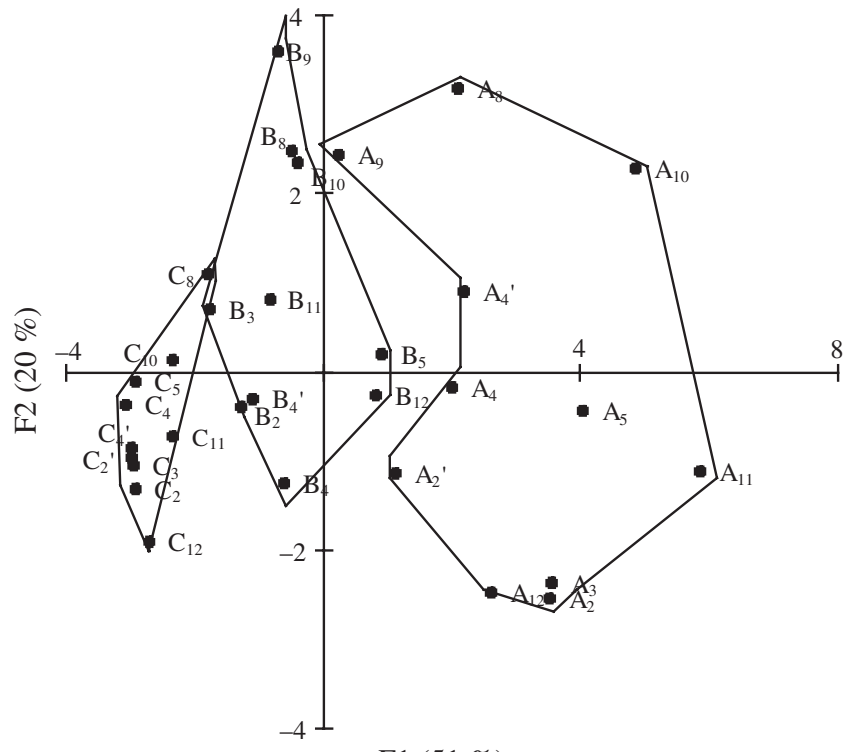

F1 $(51 \%)$

Fig. 3. PCA calculated using environmental parameters, benthic compartments and fluxes at all sampling occasions, at Stns A, B and C simultaneously. Rows lacking data were systematically deleted. The percentage of variability explained by each axis was reported. (a) Variables and (b) sampling occasions were plotted using F1 and F2. For the variables, the circle of correlations was reported. For the sampling occasions, the name of the station and the date (number of the month) were reported (e.g. $\mathrm{A}_{2}$ for Stn A in February, $\mathrm{A}_{2}{ }^{\prime}$ when 2 samples were assessed in the same month). Sampling sites were grouped
Stn $B_{i}$ SPP $=0.73-0.38 \sin [(2 \pi / 365) d+1.17]$

$$
\left(\mathrm{R}^{2}=0.942, \mathrm{n}=15\right)
$$

Stn $C_{i}$ SPP $=0.53-0.07 \sin [(2 \pi / 365) d+1.15]$

$$
\left(\mathrm{R}^{2}=0.953, \mathrm{n}=16\right)
$$

Maximum values occurred in summer $(0.8,1.1$ and $0.6 \mathrm{mgC} \mathrm{mgChl} \mathrm{a}^{-1} \mathrm{~h}^{-1}$ respectively on 1 August, and 25, 26 of July for Stns A, B and C). The empirical maximum assimilation number for microphytobenthos (1 mgC mgChl $a^{-1} \mathrm{~h}^{-1}$, Migné et al. 2004 and references therein) was reported (Fig. 5, dashed lines).
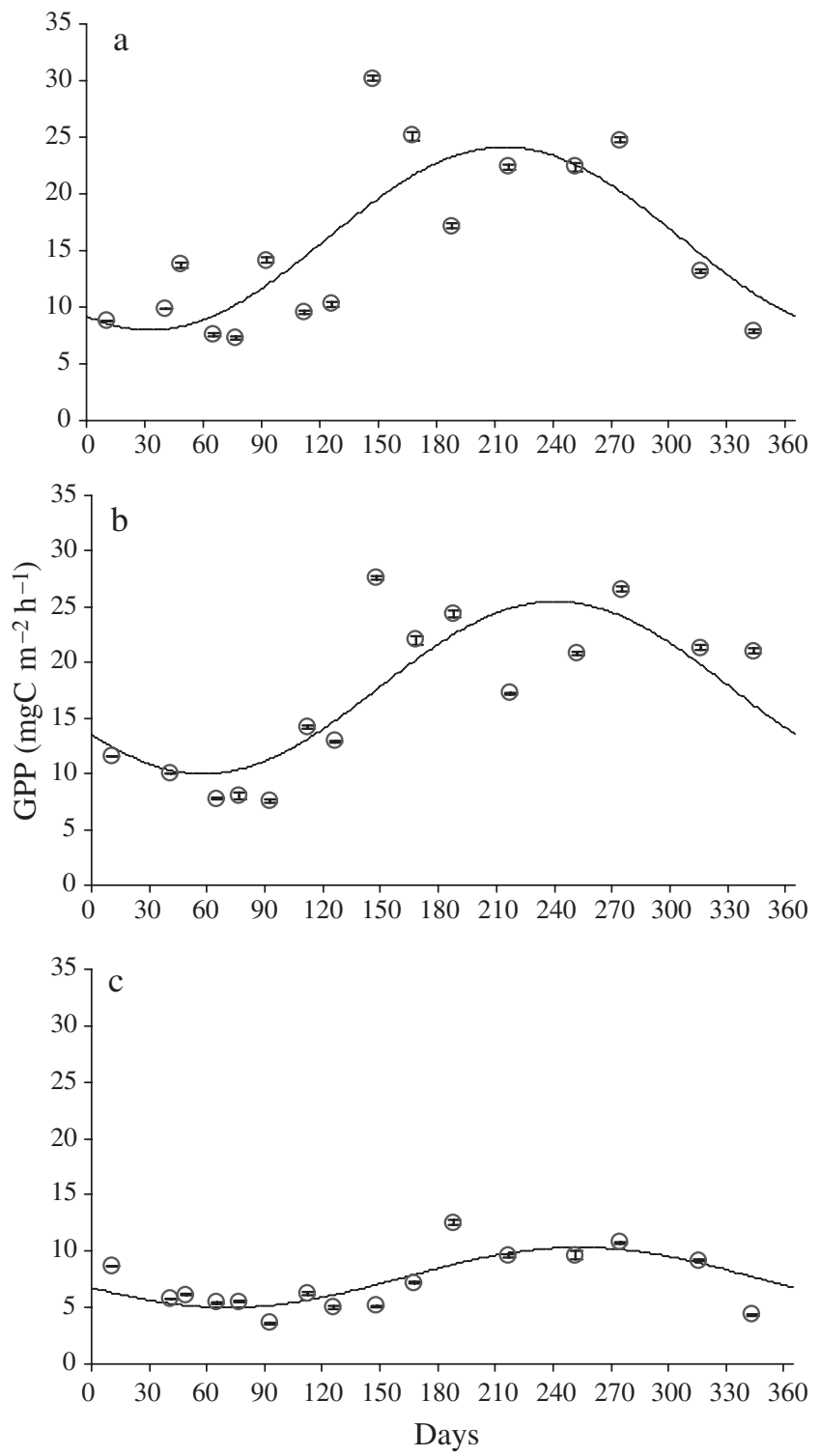

Fig. 4. Sinusoidal curve fitted on gross primary production (GPP, mg C m ${ }^{-2} \mathrm{~h}^{-1}$ ) in (a) muddy, (b) sandy, and (c) coarse sediments; for details see the text. Error bars indicate $\mathrm{SD}$ of the slope of the regression curve 
BCR also showed a seasonal pattern at all stations (Fig. 6) and was fitted with a sinusoidal model:

Stn $\mathrm{A}_{i} \mathrm{BCR}=5.84-4.25 \sin [(2 \pi / 365) d+0.99]$

$$
\left(\mathrm{R}^{2}=0.885, \mathrm{n}=16\right)
$$

Stn $\mathrm{B}_{;} \mathrm{BCR}=1.84-1.71 \sin [(2 \pi / 365) d+1.19)$

$$
\left(\mathrm{R}^{2}=0.701, \mathrm{n}=15\right)
$$

Stn $C_{i} B C R=0.49-0.41 \sin [(2 \pi / 365) d+0.86]$

$$
\left(\mathrm{R}^{2}=0.473, \mathrm{n}=16\right)
$$

Maximum BCR values occurred in summer (10.1, 3.5 and $0.9 \mathrm{mg} \mathrm{C} \mathrm{m}^{-2} \mathrm{~h}^{-1}$, respectively, on 5 August, 24 July
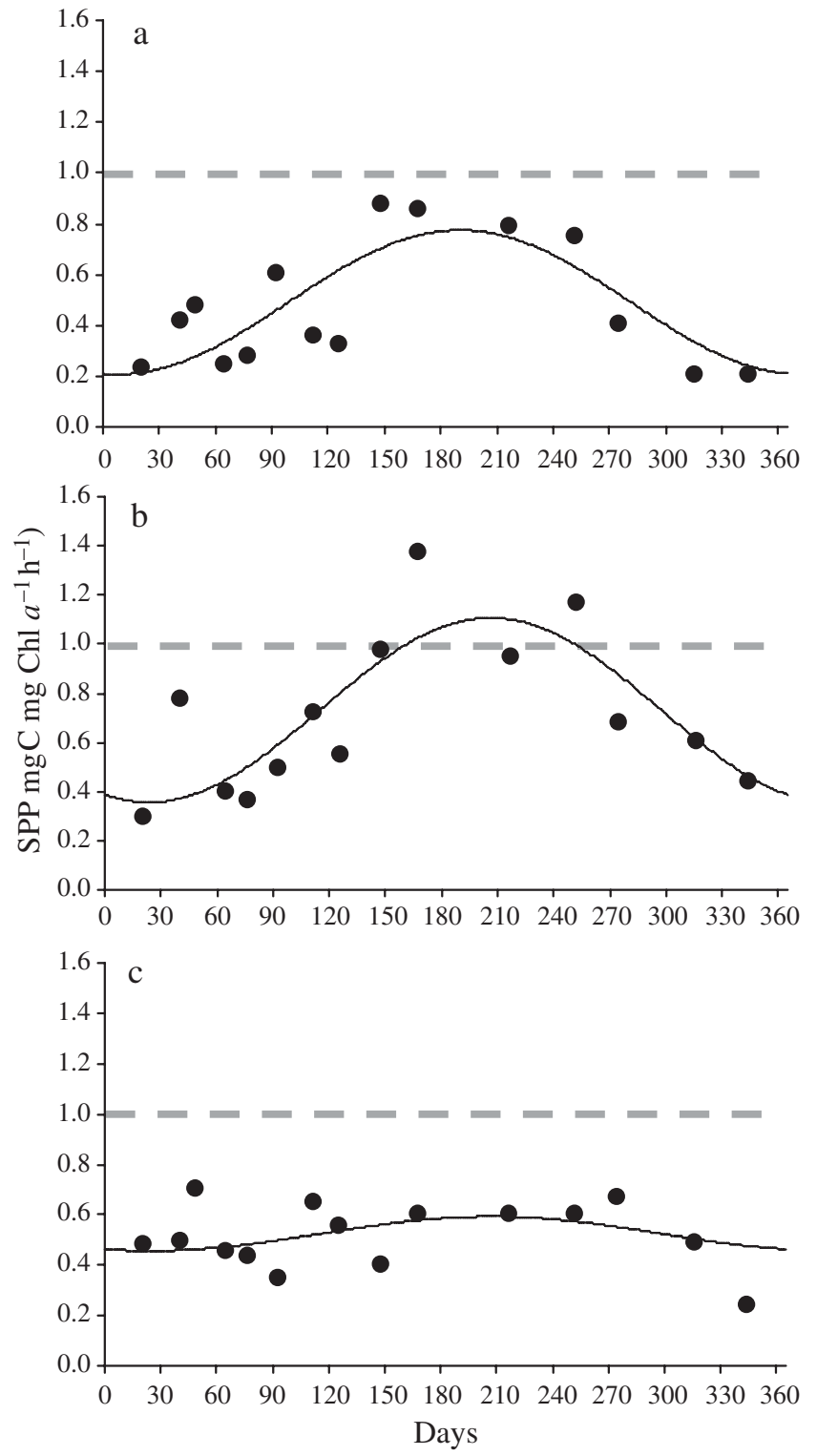

Fig. 5. Sinusoidal curve fitted on specific primary production $\left(\mathrm{P}: \mathrm{B}\right.$ ratio $\left.=\mathrm{SPP}, \mathrm{mgC} \mathrm{mgChl} \mathrm{a}^{-1} \mathrm{~h}^{-1}\right)$ data in (a) muddy, (b) sandy, and (c) coarse sediments; for details see the text. Dashed line represents the maximum assimilation number recorded in intact cores for benthic microalgae and 12 August for Stns A, B and C). BCR rates were significantly different between the 3 sampling sites (Kruskal-Wallis, $\mathrm{p}<0.01)$ being higher at Stn A $(5.4 \pm$ $\left.3.9 \mathrm{mgC} \mathrm{m}^{-2} \mathrm{~h}^{-1}\right)$ than at Stns B $\left(1.7 \pm 2.1 \mathrm{mg} \mathrm{C} \mathrm{m}^{-2} \mathrm{~h}^{-1}\right)$ and $\mathrm{C}\left(0.4 \pm 0.8 \mathrm{mg} \mathrm{C} \mathrm{m}^{-2} \mathrm{~h}^{-1}\right)$.

Effect of temperature was tested both on BCR and GPP. Significant exponential curves and cardinal temperature models were reported (Fig. 7). Temperature coefficients $\left(Q_{10}\right)$, which indicated an increase in GPP and $\mathrm{BCR}$ rates for a $10^{\circ} \mathrm{C}$ rise in temperature, were calculated (Tables 1 \& 2). Optimal temperature at Stn A was $21^{\circ} \mathrm{C}$.
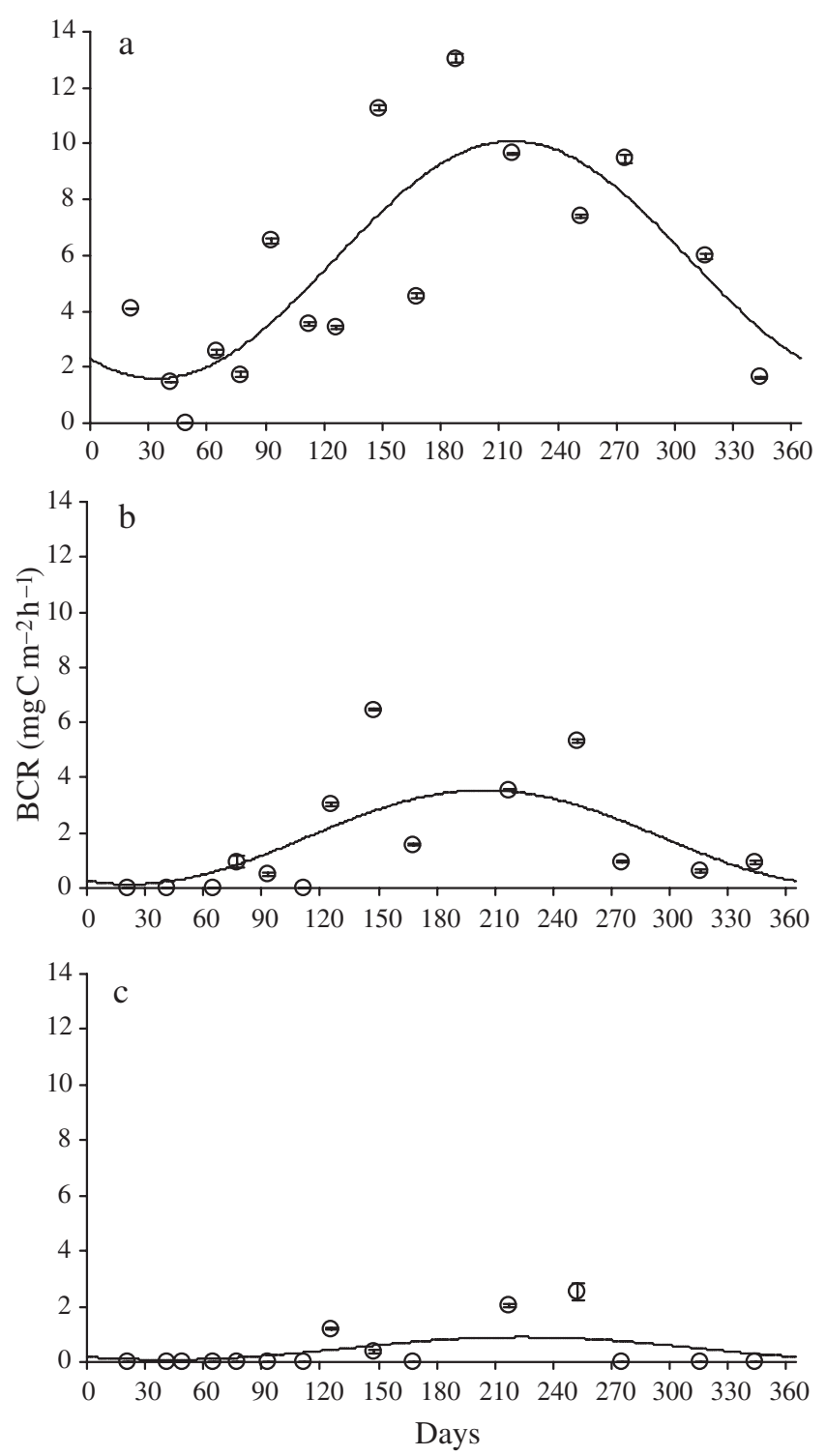

Fig. 6. Sinusoidal curve fitted on benthic community respiration (BCR, $\mathrm{mgC} \mathrm{m}^{-2} \mathrm{~h}^{-1}$ ) data in (a) muddy, (b) sandy, and (c) coarse sediments, for details see the text. Error bars indicate SD of the slope of the regression curve 

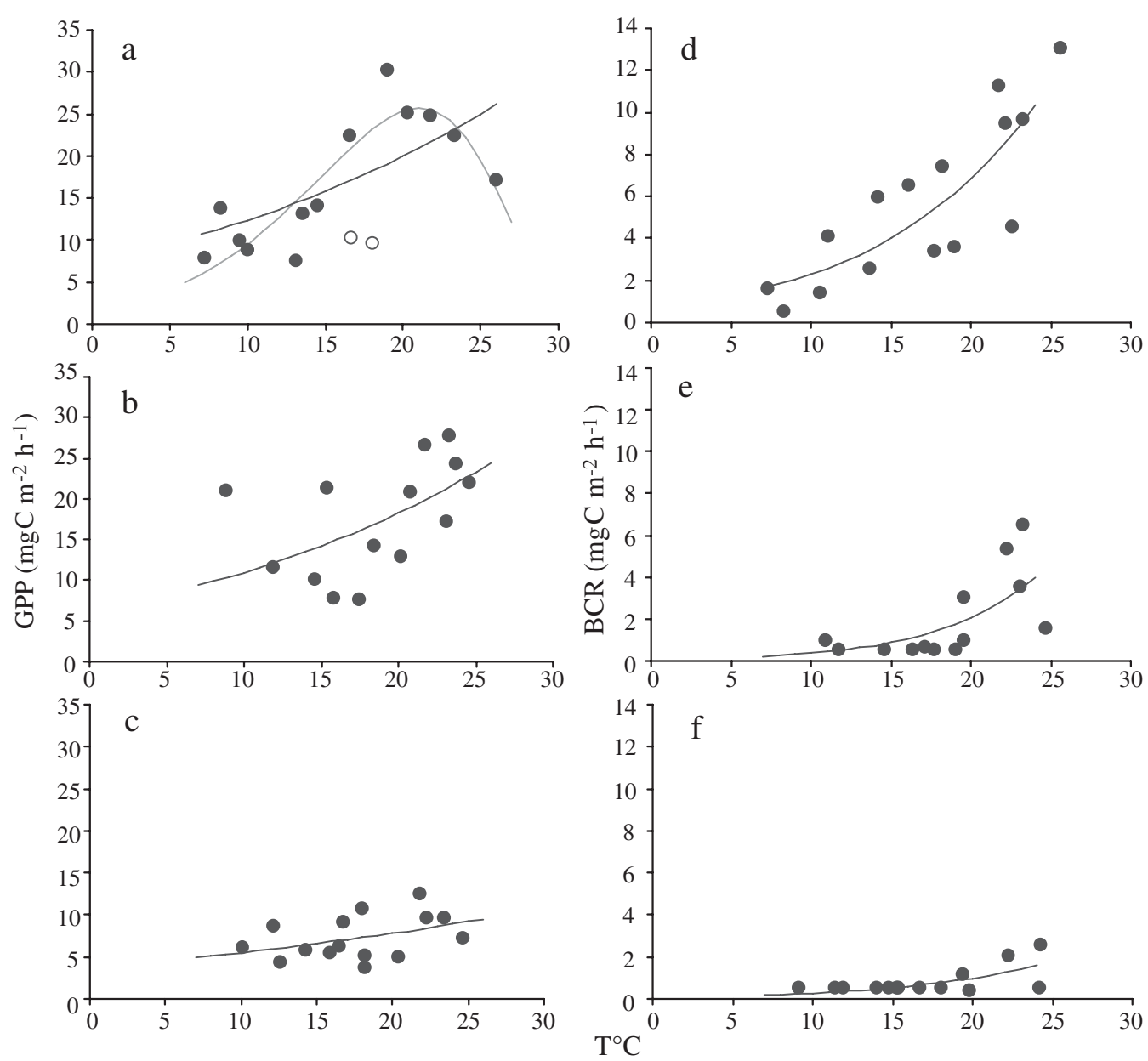

Fig. 7. GPP- and BCR-temperature response curves in $(a, d)$ muddy, $(b, e)$ sandy, and $(c$, f) coarse sediments. o: data that did not fit to the non-linear regression. — : metabolism-temperature response curve using the Arrhenius plot. —: metabolismtemperature response curve using the cardinal temperature criteria

\section{Microphytobenthos and bacteria biomass}

Chl a ranged from 23.4 to $63.6,12.9$ to 47.9 and 7.3 to $18.8 \mathrm{mgChl} \mathrm{a} \mathrm{m} \mathrm{m}^{-2}$ at Stns $\mathrm{A}, \mathrm{B}$ and $\mathrm{C}$, respectively (Fig. 8). At Stns A and B, Chl a appeared relatively stable from February to September (respectively from 23 to 37 and from 15 to $23 \mathrm{mg} \mathrm{m}^{-2}$ ) then increased in autumn. At Stn C, Chl a concentrations appeared relatively stable over the entire year. Statistical analysis showed significant differences in $\mathrm{Chl}$ a between sampling sites (Kruskal-Wallis, $\mathrm{p}<0.01$ ). Concentration was higher at Stn A $(34.4 \pm 11.9)$ and B $(24.6 \pm 10.7)$ than at $\operatorname{Stn} C(13.1 \pm 3.6)$.

Bacterial abundance ranged from 0.8 to $1.8,0.4$ to 1.4 and 0.2 to $1.1 \times 10^{8}$ cells cm ${ }^{-2}$ at Stns A, B and C, respectively. Biomass values reported in this study were within the range reported in the literature for intertidal mud- and sand-flats (Lucas et al. 1996, Epstein et al. 1997, Goñi-Urriza et al. 1999, Böttcher et al. 2000, Danovaro et al. 2001). BB showed a seasonal pattern
(Fig. 9) and sinusoidal curves were fitted on BB data:

$$
\begin{gathered}
\text { Stn } A_{i} B B=27.28+5.38 \sin [(2 \pi / 365) d+4.62] \\
\left(\mathrm{R}^{2}=0.967, \mathrm{n}=16\right) \\
\text { Stn } \mathrm{B}_{;} \mathrm{BB}=18.92+6.41 \sin [(2 \pi / 365) d+10.12] \\
\left(\mathrm{R}^{2}=0.967, \mathrm{n}=15\right) \\
\text { Stn } C_{i} \mathrm{BB}=10.33+5.65 \sin [(2 \pi / 365) d+10.67] \\
\left(\mathrm{R}^{2}=0.937, \mathrm{n}=16\right)
\end{gathered}
$$

Maximum BB occurred in summer (32.7, 25.3 and 16.0 mgC m${ }^{-2}$, respectively, on 7 July, 21 August, and 21 July for Stns A, B and C).

\section{Meiofauna and macrofauna biomass}

Maximum MeB occurred in spring at Stns A and B and was relatively stable throughout the year at Stn C (Fig. 10a-c). Statistical analysis showed significant differences in MeB between the 3 sampling sites 
Table 1. Metabolism temperature response curve parameters calculated from non-linear regression using both cardinal temperature criteria and an Arrhenius plot, for Stns A, B and C. Pre-exponential factor $\left(A_{\mathrm{i}}\right)$, and apparent activation energy $\left(E_{\mathrm{ai}}, \mathrm{kJ}\right.$ mol $\left.{ }^{-1}\right)$ are reported for the Arrhenius plot. Optimal temperature $\left(\mathrm{T}_{\text {opt }}{ }^{\circ} \mathrm{C}\right)$, maximum temperature $\left(\mathrm{T}_{\max }{ }^{\circ} \mathrm{C}\right)$ and maximum $\mathrm{GPP}(\mathrm{GPP} \mathrm{max}$ $\mathrm{mg} \mathrm{C} \mathrm{m}{ }^{-2} \mathrm{~h}^{-1}$ ) are reported for the cardinal temperature model. For all the models adjusted $\mathrm{R}^{2}\left(\mathrm{R}_{\mathrm{a}}^{2}\right.$, mean corrected $\mathrm{R}$-square: 1 -Residual/Corrected), number of couple values (n) and metabolism response to a $10^{\circ} \mathrm{C}$ rise of temperature $\left(Q_{10}\right)$ are shown. ${ }^{*} p$-values $<0.001$

\begin{tabular}{|c|c|c|c|c|c|c|c|c|}
\hline GPP & $A_{\mathrm{i}}$ & $\begin{array}{c}E_{\mathrm{ai}} \\
\left(\mathrm{kJ} \mathrm{mol}^{-1}\right)\end{array}$ & $\mathrm{T}_{\mathrm{opt}}{ }^{\circ} \mathrm{C}$ & $\mathrm{T}_{\max }{ }^{\circ} \mathrm{C}$ & $\underset{\left(\mathrm{mgC} \mathrm{m}^{-2} \mathrm{~h}^{-1}\right)}{\mathrm{GPP}_{\max }}$ & $\mathrm{R}_{\mathrm{a}}^{2}$ & $\mathrm{n}$ & $Q_{10}$ \\
\hline \multicolumn{9}{|l|}{ Arrhenius plot } \\
\hline A & $1.4 \times 10^{7}$ & 32.8 & - & - & - & $0.49^{*}$ & 13 & 1.6 \\
\hline $\mathrm{B}$ & $3.5 \times 10^{7}$ & 35.2 & - & - & - & $0.27^{*}$ & 14 & 1.7 \\
\hline $\mathrm{C}$ & $1.5 \times 10^{5}$ & 24.0 & - & - & - & $0.16^{*}$ & 15 & 1.4 \\
\hline \multicolumn{9}{|l|}{ Cardinal temperature } \\
\hline A & - & - & 21.0 & 32.5 & 25.7 & $0.79^{*}$ & 13 & 2.7 \\
\hline
\end{tabular}

Table 2. BCR temperature response curve parameters calculated from non-linear regression using an Arrhenius plot, for Stns A, B and C. Pre-exponential factor $\left(A_{\mathrm{i}}\right)$, apparent activation energy $\left(E_{\text {air }} \mathrm{kJ} \mathrm{mol}^{-1}\right)$, adjusted $\mathrm{R}^{2}\left(\mathrm{R}^{2}{ }_{a}\right.$, mean corrected $\mathrm{R}^{2}=1$-Residual/Corrected), number of couple values (n) and metabolism response to a $10^{\circ} \mathrm{C}$ rise of temperature $\left(Q_{10}\right)$ are shown. *indicates $\mathrm{p}$-value $<0.001$

\begin{tabular}{|lcclll|}
\hline BCR & \multicolumn{1}{c}{$A_{\mathrm{i}}$} & $\begin{array}{c}E_{\mathrm{ai}} \\
\left(\mathrm{kJ} \mathrm{mol}^{-1}\right)\end{array}$ & $\mathrm{R}^{2}{ }_{\mathrm{a}}$ & $\mathrm{n}$ & $Q_{10}$ \\
\hline \multicolumn{2}{c}{ Arrhenius plot } & & & & \\
$\mathrm{A}$ & $1.5 \times 10^{14}$ & 74.8 & $0.71^{*}$ & 15 & 3.0 \\
$\mathrm{~B}$ & $4.5 \times 10^{21}$ & 119.7 & $0.44^{*}$ & 13 & 5.7 \\
$\mathrm{C}$ & $3.6 \times 10^{15}$ & 87.3 & $0.44^{*}$ & 14 & 3.5 \\
\hline
\end{tabular}

(Kruskal-Wallis, $\mathrm{p}<0.01$ ). The taxonomic composition was similar among the 3 sampling sites. Nematoda was the predominant taxonomic group during the year and represented (mean $\pm \mathrm{SD}$ ) $77 \pm 13,80 \pm 9$ and $79 \pm 9 \%$ of meiofaunal abundance at Stns A, B and C, respectively, which was consistent with previous studies carried out in the Roscoff Aber Bay (Riera \& Hubas 2003) under similar conditions. The co-occurring main taxonomic groups were ostracods and harpacticoid copepods, together they represented $20 \pm 11,18 \pm 6$ and $9 \pm$ $5 \%$ of meiofauna at Stns A, B and C, respectively.

Statistical analysis also showed significant differences in $\mathrm{MaB}$ between the 3 sampling sites (KruskalWallis, $\mathrm{p}<0.01$ ). MaB ranged from 6.7 to $29.3,0.8$ to 9.2 and 0.6 to $3.3 \mathrm{~g} \mathrm{AFDW} \mathrm{m}^{-2}$ at Stns A, B and C respectively (Fig. 10d,e,f). The specific diversity was also radically different between the 3 sampling sites. Station A was dominated by species typically found in mud and muddy sand (Hayward \& Ryland 1995), like the mud snail Hydrobia ulvae, the amphipoda Corophium arenarium and the bivalvia Cerastoderma edule and Abra tenuis which represented $97 \pm 3 \%$ of macrofauna biomass ( $61 \pm 12 \%$ for $H$. ulvae alone). At Stn B, C. edule and $A$. tenuis were also present with the polychaeta Scoloplos armiger and Pygospio elegans (85 $\pm 12 \%$ of macrofaunal biomass), which both prefer fine sand (Hayward \& Ryland 1995). At Stn C, macrofauna biomass was dominated by $C$. edule, $S$. armiger, Notomastus latericeus and the Tanaïdacea Apseudes latreillii (74 $\pm 19 \%$ of macrofauna biomass) who prefer muddy gravels (Hayward \& Ryland 1995).

\section{Multiple regression analysis}

Multiple regressions were assessed using (1) nutrients and (2) benthic compartments as independent parameters to determine the best predictors of GPP and BCR (Tables 3,4).

For GPP (Table 3), DIN and DIP coefficients and standardized coefficients were always higher (absolute values) than DISi coefficients (except at Stn A). Significant coefficients changed among the 3 sampling sites (DIN and DIP at Stn B, DIP only at Stn C). However, DIP was always recorded as a pertinent variable (best fit).

For BCR (Table 4), although $\mathrm{R}^{2}$ was not significant for muddy sandy and coarse sediments, the analysis showed that $\mathrm{BB}$ coefficients were always higher than MaB, MeB and MPB coefficients. Moreover, BB standardized coefficients were also higher than $\mathrm{MaB}, \mathrm{MeB}$ and MPB standardized coefficients. BB coefficients were also always significant except in muddy sediment. BB was always recorded as a pertinent variable (best fit) with $\mathrm{MaB}$ except in coarse sediments where $\mathrm{BB}$ alone was recorded as a pertinent variable (highest coefficient, best fit).

\section{DISCUSSION}

\section{Control of benthic metabolism at the bay scale}

Metabolic activity of benthic organisms can be influenced by a wide range of regulating factors. In this study, the Roscoff Aber Bay represented a strong 
Table 3. Multiple linear regressions between GPP $\left(\mathrm{mg} \mathrm{C} \mathrm{m}^{-2} \mathrm{~h}^{-1}\right)$ and dissolved inorganic nitrogen (DIN), phosphates (DIP) and silicates (DISi) in $\mu \mathrm{mol} \mathrm{l}^{-1}$, Constant (Cst), standardized $\left(\mathrm{Std} \mathrm{C}_{\mathrm{i}}\right.$ ) and non-standardized $\left(\mathrm{C}_{\mathrm{i}}\right)$ variable coefficients were reported. Pvalues associated to variable coefficients were calculated $(\mathrm{p})$ and pertinent variables (best fit) were noted (X). Parameters were calculated at the sampling site scale (Stns A, B and C). Bold values were significant

\begin{tabular}{|c|c|c|c|c|c|c|c|c|c|c|c|c|}
\hline \multirow{2}{*}{ GPP } & \multicolumn{4}{|c|}{ A } & \multicolumn{4}{|c|}{$-B$} & \multicolumn{4}{|c|}{ C } \\
\hline & $\mathrm{C}_{\mathrm{i}}$ & Std $C_{i}$ & $\mathrm{p}$ & Best fit & $\mathrm{C}_{\mathrm{i}}$ & Std $C_{i}$ & $\mathrm{p}$ & Best fit & $\mathrm{C}_{\mathrm{i}}$ & Std $C_{i}$ & $\mathrm{p}$ & Best fit \\
\hline Cst & 18.30 & - & 0.002 & & 21.94 & - & 0.0001 & & 5.12 & - & 0.002 & \\
\hline DIN & 0.02 & 0.16 & 0.35 & & -0.41 & -1.53 & 0.002 & $\mathrm{X}$ & -0.07 & -0.20 & 0.29 & \\
\hline DISi & -0.02 & -0.19 & 0.31 & & 0.004 & 0.01 & 0.48 & & 0.01 & 0.03 & 0.45 & \\
\hline DIP & -0.53 & -0.52 & 0.08 & $\mathrm{X}$ & 4.16 & 1.35 & 0.004 & $\mathrm{X}$ & 2.17 & 0.94 & 0.01 & $\mathrm{X}$ \\
\hline Model & & & 0.40 & $\mathrm{R}^{2}=0.27$ & & & 0.03 & $\mathrm{R}^{2}=\mathbf{0 . 6 7}$ & & & 0.03 & $\mathrm{R}^{2}=\mathbf{0 . 6 2}$ \\
\hline
\end{tabular}
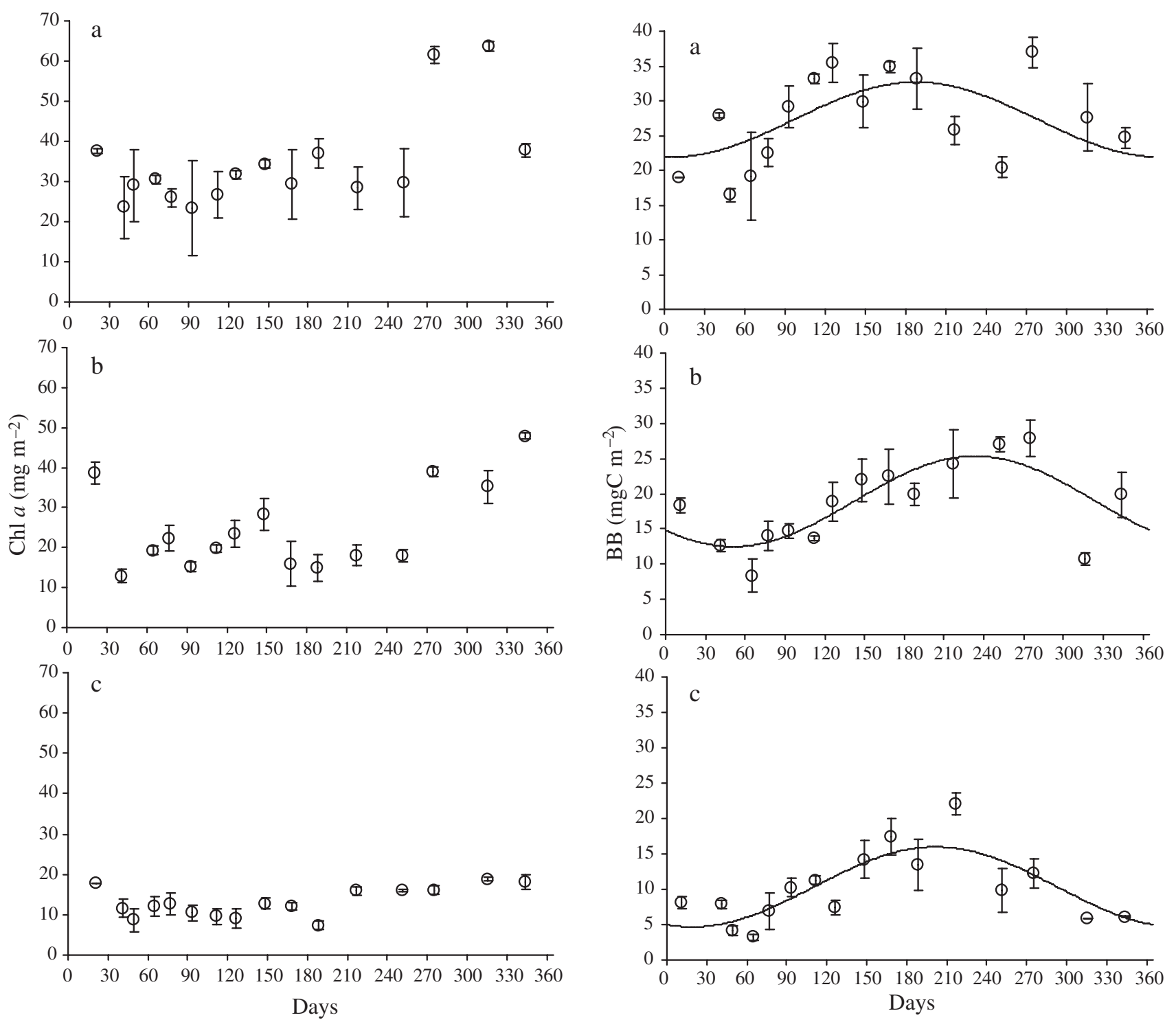

Fig. 8. Chl a concentration in surface sediment $(0.2 \mathrm{~cm})$ in (a) muddy, (b) sandy, and (c) coarse sediments. Error bars indicate spatial variability (triplicates)

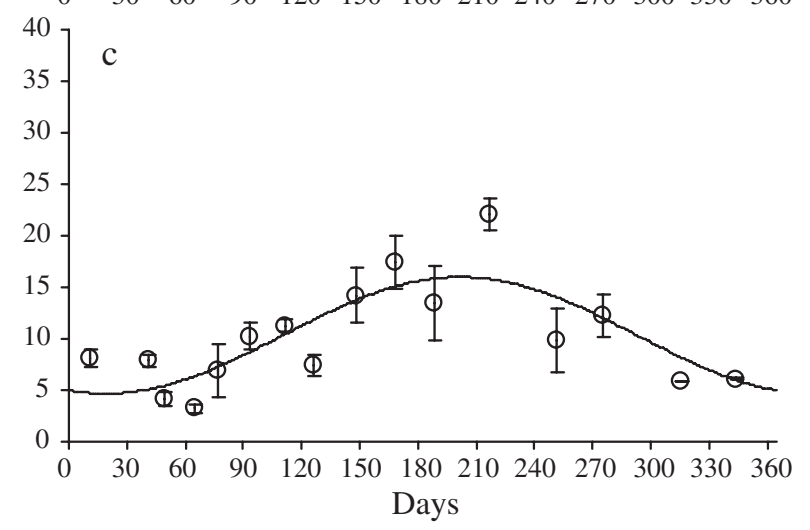

Fig. 9. Sinusoidal curve fitted on bacterial biomass (BB) in (a) muddy, (b) sandy, and (c) coarse sediments, for details see the text. Error bars indicate spatial variability (triplicates) 
environmental gradient which directly constrained the dynamics of benthic organisms. PCA explained $71 \%$ of the total variability. At the bay scale, PCA showed that the granulometric gradient strongly controlled the dynamics of benthic organisms and the concentration of nutrients in sediments (i.e. median grain size was contributing to F1 together with $\mathrm{BB}, \mathrm{MaB}, \mathrm{MeB}$, and nutrients but not with benthic fluxes). However, at sampling site scale (i.e. within each sampling site) the functioning of the system was mostly influenced by seasonal variations (i.e. temperature was contributing to F2 together with GPP, BCR and SPP but not with nutrients and benthic compartments).

Table 4. Multiple linear regressions between $\mathrm{BCR}\left(\mathrm{mg} \mathrm{C} \mathrm{m}^{-2} \mathrm{~h}^{-1}\right)$ and benthic compartments (bacteria biomass: $\mathrm{BB}, \mathrm{gC} \mathrm{m}^{-2}$; meio-

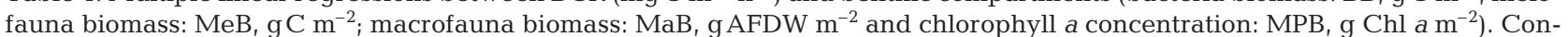
stant (Cst), standardized (Std $\left.\mathrm{C}_{\mathrm{i}}\right)$ and non standardized $\left(\mathrm{C}_{\mathrm{i}}\right)$ variable coefficients were reported. P-values associated to variables coefficients were calculated $(\mathrm{p})$ and pertinent variables (best fit) were noted (X). Parameters were calculated at the sampling site scale (Stns A, B and C). Bold values were significant

\begin{tabular}{|c|c|c|c|c|c|c|c|c|c|c|c|c|}
\hline \multirow{2}{*}{ BCR } & \multicolumn{4}{|c|}{ A } & \multicolumn{4}{|c|}{$B$} & \multicolumn{4}{|c|}{$C$} \\
\hline & $\mathrm{C}_{\mathrm{i}}$ & Std $C_{i}$ & $\mathrm{p}$ & Best fit & $\mathrm{C}_{\mathrm{i}}$ & Std $C_{i}$ & $\mathrm{p}$ & Best fit & $\mathrm{C}_{\mathrm{i}}$ & Std $C_{i}$ & $\mathrm{p}$ & Best fit \\
\hline Cst & -2.03 & - & 0.38 & & -4.07 & _- & 0.09 & & -0.40 & - & 0.33 & \\
\hline BB & 172.86 & 0.29 & 0.18 & $\mathrm{X}$ & 275.86 & 0.80 & 0.02 & $\mathrm{X}$ & 75.85 & 0.66 & 0.04 & $\mathrm{X}$ \\
\hline MeB & -0.60 & -0.08 & 0.38 & & 0.62 & 0.11 & 0.38 & & -0.42 & -0.17 & 0.32 & \\
\hline MaB & 0.14 & 0.22 & 0.26 & $\mathrm{X}$ & 0.23 & 0.31 & 0.21 & $\mathrm{X}$ & 0.07 & 0.10 & 0.37 & \\
\hline MPB & 36.35 & 0.11 & 0.36 & & -43.58 & -0.22 & 0.23 & & -0.76 & -0.004 & 0.49 & \\
\hline Model & & & 0.43 & $\mathrm{R}^{2}=0.27$ & & & 0.11 & $\mathrm{R}^{2}=0.54$ & & & 0.37 & $\mathrm{R}^{2}=0.35$ \\
\hline
\end{tabular}
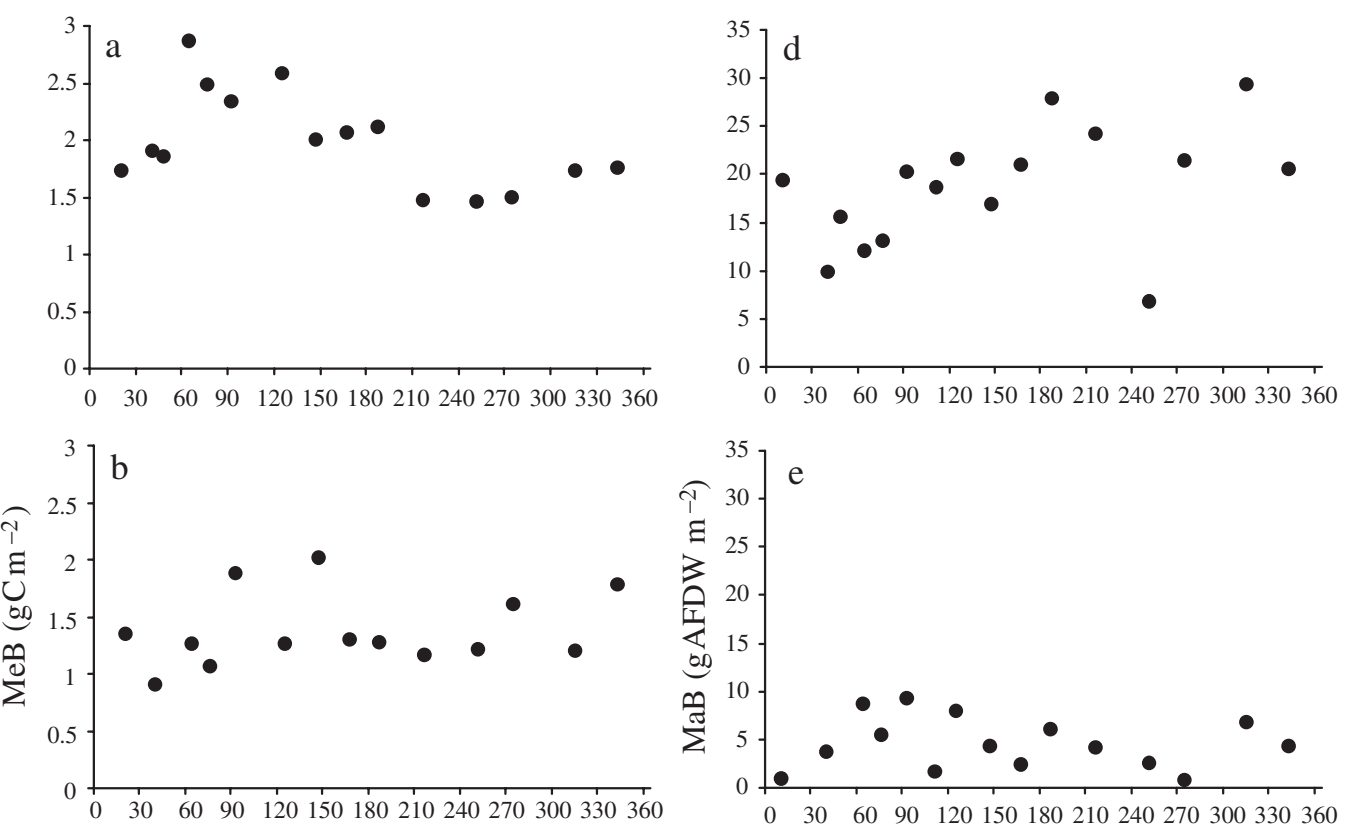

Fig. 10. Meiofaunal (MeB, $\mathrm{gC} \mathrm{m}^{-2}$ ) and macrofaunal $\left(\mathrm{MaB}, \mathrm{g} A F D W \mathrm{~m}^{-2}\right)$ biomass in $(a, d)$ muddy, $(b, e)$ sandy, and $(\mathrm{c}, \mathrm{f})$ coarse sediments
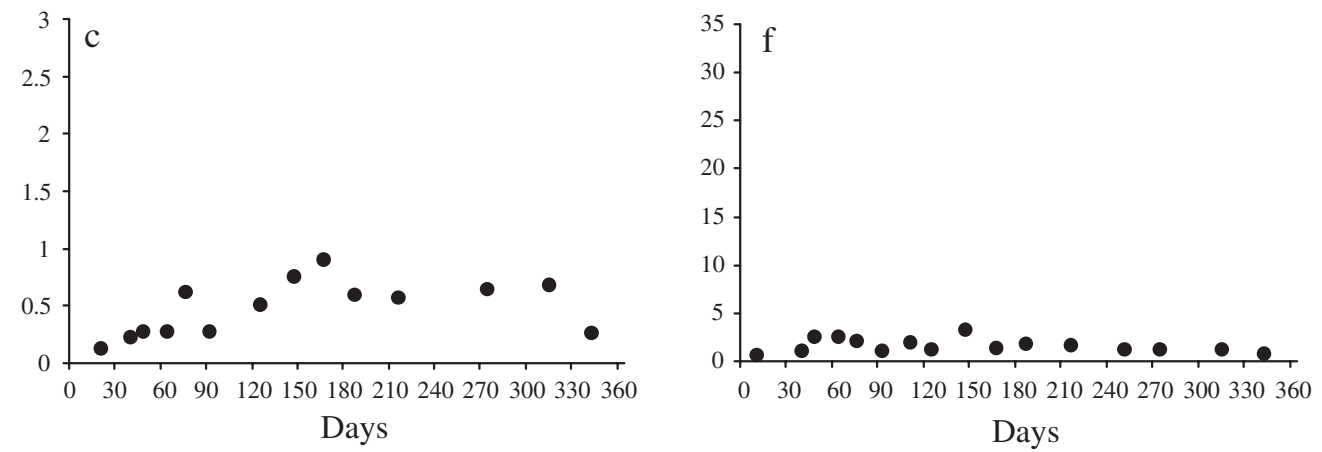


\section{Temperature influence on benthic metabolism at sampling site scale}

Incident light intensity is known to be of primary importance in determining seasonal patterns of primary production in sediments (Parsons et al. 1984). However, environmental factors like salinity, temperature (Rasmussen et al. 1983, Blanchard et al. 1996, Blanchard \& Guarini 1997), day:night and tidal cycles (van Es 1982, Migné et al. 2004), and nutrients concentration (Underwood \& Provot 2000) can have a significant influence.

In the Bay of Somme and the Bay of Seine (France) GPP and BCR were fitted with sinusoidal curves (Migné et al. 2004, Spilmont et al. 2006). The models showed that maximum GPP occurred in July (i.e. maximum light intensity) while maximum BCR occurred in August (i.e. maximum temperature), indicating that GPP could be preferentially controlled by light intensity. In the present study, the models indicated that maximum GPP (Fig. 4a-c) occurred later or at the same time than maximum BCR (mostly in August, Fig. 6a-c). Moreover, the PCA (Fig. 3a,b) indicated that within each sampling site benthic organism activity was probably not limited by physical and chemical parameters of the sediment (i.e. granulometry, nutrients concentrations) but rather by seasonal parameters (i.e. temperature). Thus, in the present study: (1) the seasonal cycle seemed to overrule all the scale size of other parameters and seemed to constrain the activity of benthic organisms; and (2) temperature influence seemed to be more important than light intensity in the control of benthic metabolism. In the Ems estuary, despite the strong influence of the tidal cycle and the wind action, the seasonal cycle also dominates processes related to the biota (de Jonge 2000).

The effect of temperature fluctuation on GPP is well established, particularly on exposed tidal flats (Admiraal 1977, Rasmussen et al. 1983, Blanchard et al. 1996, Hancke \& Glud 2004). However, comparison between studies is complex due to different laboratory and in situ techniques. In the Roscoff Aber Bay, since cardinal criteria strongly increased the $\mathrm{R}^{2}$ at $\mathrm{Stn}$ A: from $49 \%$ with the Arrhenius plot to $79 \%$ with cardinal temperature criteria, the latter was used to characterize the response of GPP to temperature at Stn A. GPP showed lower-end mesophilic temperature response curves at this station (with $\mathrm{T}_{\mathrm{opt}}=21^{\circ} \mathrm{C}$ ), which indicated that MPB was growing best at moderate temperatures. Moreover, $Q_{10}$ values of GPP calculated using this model were within the range of published $Q_{10}$ values. A rise of $10^{\circ} \mathrm{C}$ would increase the GPP 2-fold $\left(Q_{10} \sim 2\right.$, Davison 1991). Thus, the cardinal temperature model gave more appropriate $Q_{10}$ values than the Arrhenius plot, which was consistent with the results of Blanchard et al. (1996). Indeed, a curve with an optimum is more likely to correctly describe the metabolism increase (as a function of increasing temperature) than an ongoing exponential increase. However, at Stns B and $\mathrm{C}$ production rates are low and, compared to their magnitude, highly variable. Thus, even if the optimum is located in the observed range of temperature, it would be difficult to fit the cardinal temperature model properly. Consequently, at these stations, fitting the cardinal temperature model to data that show practically no optimum was considered to be spurious.

BCR showed strong correlations with temperature both at the bay scale and at the sampling site scale, which was consistent with previous studies (van Es 1982 and references therein). In the present study, BCR-temperature response curves did not show a decrease beyond $\mathrm{T}_{\mathrm{opt}}$. Since the exponential curves are preferentially used in the literature to explain metabolism variability versus temperature, an Arrhenius plot was used to calculate $Q_{10}$ values for BCR (Table 2). In the present study (considering the Arrhenius plot only) $Q_{10}$ were higher for BCR than for GPP. Thus, a rise of $10^{\circ} \mathrm{C}$ would stimulate heterotrophic activity more than photosynthesis. These results were consistent with Hancke \& Glud (2004). Due to low temperature variability, these authors rejected the idea that higher $Q_{10}$ for respiration was linked to a more efficient acclimation of the phototrophic community to high temperature. However, in intertidal ecosystems, temperature variability was potentially more important during exposure. Moreover, phototrophic organisms inhabiting sediments are known to adapt themselves to short term changes in light intensity through migration into the sediment layers. This is usually highlighted through photosynthesis/light intensity response curves. Indeed, in natural environments, benthic cyanobacteria (Epping \& Kühl 2000, Wieland \& Kühl 2000) and microalgae (Davis \& McIntire 1983, Rasmussen et al. 1983, Migné et al. 2004) do not show any photoinhibition (at least at the community level). In the Roscoff Aber Bay, migration probably prevented MPB from photoinhibition and high temperature. Thus, since bacterial communities were probably not able to migrate into the sediment, the higher $Q_{10}$ values recorded for BCR than for GPP were rather a consequence of behavioural processes inherent to benthic autotrophs rather than a hypothetic change of MPB physiological conditions.

\section{Nutrient and grazing pressure: significant controlling mechanisms?}

Multiple linear regression (Table 3) showed that GPP was mainly influenced by DIP and DIN, but not DISi. Annual inorganic N:P ratios were calculated and were on 
average $17 \pm 5: 1,16 \pm 5: 1,10 \pm 5: 1$ at Stns A, B and C, respectively (mean $\pm \mathrm{SD}$ ). This indicated that over the year $\mathrm{N}: \mathrm{P}$ ratios were in the same order of magnitude as the Redfield ratio (16:1). N:P ratios between 5:1 and 15:1 are commonly reported (Welker et al. 2002). In the present study, GPP was thus probably not limited by nutrients concentrations in porewater. Indeed, since concentrations recorded in porewater were high, a hypothetic limitation by nutrients would be spurious. GPP was thus more probably sustained in porewater, during low tide, by balanced nitrogen and phosphate concentrations.

At Stn A, Hydrobia ulvae was the dominant deposit feeder ( $67 \pm 15 \%$ of the macrofaunal abundance) and represented $14000 \pm 4000$ snails m ${ }^{-2}$. According to an experimental study in a similar environment (Blanchard et al. 2000) the mean ingestion rate would be $26.64 \pm 1.14 \mathrm{ngChl}$ a snail ${ }^{-1} \mathrm{~h}^{-1}$, which represented a mean ingested capacity of $0.36 \pm 0.11 \mathrm{mg} \mathrm{Chl} \mathrm{a} \mathrm{m}^{-2} \mathrm{~h}^{-1}$. Total carbon biomass ingested would be $10.8 \pm$ $3.3 \mathrm{mgC} \mathrm{m}^{-2} \mathrm{~h}^{-1}$ (considering $30 \mathrm{mgC} \mathrm{mgChl} \mathrm{a}^{-1}$; de Jonge 1980, Sundbäck et al. 2000), which was close to the mean GPP at Stn A $\left(15 \pm 7 \mathrm{mg} \mathrm{C} \mathrm{m}^{-2} \mathrm{~h}^{-1}\right)$. The H. ulvae grazing rate would therefore be totally supplied by GPP at Stn A, which indicates that microphytobenthos production would be, theoretically, limited by macrofaunal grazing pressure at Stn A. However, no significant correlation was found between $H$. ulvae biomass and GPP. Dominant deposit feeders at Stn A were therefore probably not preferentially using microphytobenthos as a food source. Macroalgae deposits which were regularly available in the Roscoff Aber Bay (Riera \& Hubas 2003) could potentially represent an important food source for them. These authors highlighted the meiofauna-microphytobenthos trophic relationship in Roscoff Bay and showed that meiofauna feeding activity on microphytobenthos was restricted to the summer period (when microphytobenthos was more important). The rest of the year, meiofauna preferentially used detrital macroalgae as a food source.

\section{Role of heterotrophic bacteria in BCR}

Quantifying the role of heterotrophic bacteria in $\mathrm{BCR}$ is of primary importance in determining the fate of organic carbon in aquatic ecosystems (Jahnke \& Craven 1995). However, to our knowledge the relative importance of bacterial respiration to BCR was never highlighted in situ in intertidal sediments. Indeed, a few studies yielded the contribution of benthic communities on BCR including the entire size range of benthic organisms (Dye 1981, van Es 1982, Schwinghamer et al. 1986, Piepenburg et al. 1995). These studies generally concluded that bacterial communities contribution to BCR is important compared to their relative low bio- mass. In the present study, the multiple linear regression (Table 4) showed that BCR was mostly influenced by BB. However, at Stn A, BB standardized coefficients were slightly higher than MaB coefficients. This could indicate that in muddy sediments $\mathrm{MaB}$ contribution to BCR was at least as important as BB contribution. With increasing sediment grain size (at Stns B and C) $\mathrm{MaB}$ contribution decreased while BB contribution increased. This was consistent with results from Piepenburg et al. (1995) and Dye (1981) for exposed sandy beaches. When MaB was important (18.6 + 6.1 g AFDW $\mathrm{m}^{-2}$ at $\left.\mathrm{Stn} A\right)$, macrofauna contribution was at least as important as BB contribution.

Direct comparison however between studies is limited. Respiration rates of the different benthic compartments are mostly calculated from conversion factors and/or from size partitioned oxygen measurements (Dye 1981, Schwinghamer et al. 1986, Grant \& Schwinghamer 1987, Piepenburg et al. 1995). Due to methodological limitation, bacterial respiration is thus never measured and the role of heterotrophic bacteria is mostly estimated from bacterial biomass production (Jahnke \& Craven 1995). In the present study, potential annual bacterial respiration was calculated from measured data. When the linear regression between BCR and $\mathrm{BB}$ was significant, potential bacterial respiration was calculated (Stn B: BCR $=0.21 \mathrm{BB}-2.19, \mathrm{r}=0.62, \mathrm{n}=$ $14, \mathrm{p}<0.01)$. The slope of the linear regression gave the maximum bacterial respiration efficiency (BRE, $\mathrm{h}^{-1}$ ) at Stn B. BRE was multiplied to BB (at each sampling occasion) to give potential bacterial respiration

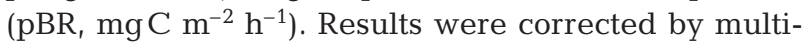
plying $\mathrm{pBR}$ by the $\mathrm{R}^{2}$ of the linear regression. Mean bacterial respiration was estimated to $1.5 \pm 0.5 \mathrm{mgC}$ $\mathrm{m}^{-2} \mathrm{~h}^{-1}$ and would represent $88 \%$ of BCR at Stn B. Thus, BCR regression against BB gave a good estimation of bacterial respiration in intertidal sediment during emersion. Yet, uncertainties were associated with this estimation: conversion factors were used for BB calculation and BRE was probably not constant over the year. Moreover, in intertidal sediments nanoflagellates and ciliates could be responsible for removing up to $53 \%$ of the bacterial production (Epstein 1997). In the present study, these organisms probably contributed to the BCR. However, due to the sonication, the protocol proposed in the present study did not allow the quantification of flagellates and ciliates. Thus, estimation of the bacterial abundance would be overestimated with DAPI counts (i.e. only a small fraction of the bacterial community is active, Zweifel \& Hagström 1995, Choi et al. 1996), rather than overestimation by counting bacteria plus ciliates. The bacterial respiration estimation proposed in this study was thus based on bacterial biomass only and would represent the contribution of bacteria only. 


\section{CONCLUSION}

In the present study the dynamics of benthic organisms was directly constrained by the strong environmental gradient (i.e. granulometry) at the bay scale. However, within each sampling site benthic organism activity was probably not limited by physical and chemical parameters of the sediment (i.e. granulometry, nutrients concentrations), but rather by temperature. At all the sampling sites, GPP was probably neither influenced by meiofauna nor by macrofauna grazing pressure (i.e. no correlative evidence). Nutrient standing stocks in sediment porewater were abundant and not limiting, and GPP was probably sustained during low tide by a balanced N:P ratio.

These results indicated that temperature influence should be taken into account in order to draw predictive models. The cardinal temperature criteria model proposed by Blanchard et al. (1996) can be used when typical metabolism-temperature response curves are observed. In the present study, GPP in muddy sediments showed lower-end mesophilic temperature responses and temperature influence was more important for BCR than for GPP ( $Q_{10}$ values were higher for BCR than for GPP). This was thought to be due to the migration of benthic diatoms which protect microalgae from high temperature and photoinhibition.

The role of bacterial communities in BCR was also revealed: (1) BB seasonal patterns were similar to BCR seasonal pattern; and (2) the multivariate analysis showed that bacterial communities were mostly contributing to community respiration. Potential bacterial respiration could represent up to $88 \%$ of BCR in intertidal fine-sand sediments. According to Jahnke \& Craven (1995) further studies should focus on the determination of BB production coupled to BCR measurements (or at least directly bacterial respiration) in order to understand the role of bacterial communities in the carbon cycle.

Acknowledgements. The authors thank anonymous reviewers for improving the manuscript and specifically $\mathrm{V}$. N de Jonge, who significantly contributed to upgrading this document.

\section{LITERATURE CITED}

Admiraal W (1977) Influence of light and temperature on the growth rate of estuarine benthic diatoms in culture. Mar Biol 39:1-9

Bendschneider K, Robinson RJ (1952) A new spectrometric method for the determination of nitrite in sea water. J Mar Res 11:87-96

Blanchard GF, Guarini JM (1997) Studying the role of mud temperature on the hourly variation of the photosynthetic capacity of microphytobenthos in intertidal areas. C R Acad Sci Paris, Life Sci, 319(12):1153-1158
Blanchard GF, Guarini JM, Richard P, Gros P, Mornet F (1996) Quantifying the short-term temperature effect on lightsaturated photosynthesis on intertidal microphytobenthos. Mar Ecol Prog Ser 134:309-313

Blanchard GF, Guarini JM, Provot L, Richard P, Sauriau PG (2000) Measurement of ingestion rate of Hydrobia ulvae (Pennant) on intertidal epipelic microalgae: the effect of mud snail density. J Exp Mar Biol Ecol 255:247-260

Böttcher ME, Hespenheide B, Llobet-Brossa E and 7 others (2000) The biogeochemistry, stable isotope geochemistry, and microbial community structure of a temperate intertidal mudflat: an integrated study. Cont Shelf Res 20: $1749-1769$

Burgess R (2001) An improved protocol for separating meiofauna from sediments using colloidal silica sols. Mar Ecol Prog Ser 214:161-165

Chauris L (1988) L'anse de l'Aber en Roscoff, un ancien marais littoral envahi par la mer. Penn Bed (Brest) 128: $1-10$

Chevaldonné P, Godfroy A (1997) Enumeration of microorganisms from deep sea hydrothermal chimmey samples. FEMS Microbiol Lett 146:211-216

Cho CB, Azam F (1990) Biogeochemical significance of bacterial biomass in the ocean's eutrophic zone. Mar Ecol Prog Ser 63:253-259

Choi JW, Sherr EB, Sherr BF (1996) Relation between presence/absence of a visible nucleoid and metabolic activity in bacterioplankton cells. Limnol Oceanogr 41: $1161-1168$

Coull BC, Bell SS (1979) Perspectives in meiofaunal ecology. In: Livingston RJ (ed) Ecological process in coastal and marine systems. Plenum Press, New York, p 189-216

Danovo R, Armeni M, Dell'Anno A, Fabiano M, Manini E, Marrale D, Pusceddu A, Vanucci S (2001) Small-scale distribution of bacteria, enzymatic activities, and organic matter in coastal sediments. Microb Ecol 42:177-185

Davis MW, McIntire CD (1983) Effects of physical gradients on the production dynamics of sediment-associated algae. Mar Ecol Prog Ser 13:103-114

Davison IR (1991) Environmental effects on alga photosynthesis: temperature. J Phycol 27:2-8

de Jonge VN (1980) Fluctuation in the organic carbon to chlorophyll a ratios for the estuarine benthic diatom populations. Mar Ecol Prog Ser 2:345-353

de Jonge VN (2000) Importance of temporal and spatial scales in applying biological and physical process knowledge in coastal management, an example for the Ems estuary. Cont Shelf Res 20:1655-1686

de Jonge VN, Bouwman LA (1977) A simple density separation technique for quantitative isolation of meiobenthos using the colloidal silica Ludox ${ }^{\mathrm{TM}}$. Mar Biol 42:143-148

de Jonge VN, van Beusekom (1992) Contribution of resuspended microphytobenthos to total phytoplankton in the Ems estuary and its possible role for grazers. Neth J Sea Res 30:91-105

de Jonge VN, van Beusekom (1995) Wind- and tide-induced resuspension of sediment and microphytobenthos from tidal flats in the Ems estuary. Limnol Oceanogr 40(4): 766-778

Delgado M, de Jonge VN, Peletier H (1991) Experiments on resuspension of natural microphytobenthos populations. Mar Biol 108(2):321-328

Delmas D, Frikha MG, Reymond H, Linley EAS, Collos Y (1992) Long term microbial community dynamics in a coastal marine pond. Mar Microb Food Webs. 6(1):39-54

Dye AH (1981) A study of benthic oxygen consumption on exposed sandy beaches. Estuar Coast Shelf Sci 13:671-680 
Epping E, Kühl M (2000) The response of photosynthesis and oxygen consumption to short-term changes in temperature and irradiance in a cyanobacterial mat (Ebro Delta, Spain). Environ Microbiol 2(4):465-474

Epstein SS (1997a) Microbial food webs in marine sediments. I. Trophic interactions and grazing rates in two tidal flat communities. Microb Ecol 34:188-198

Epstein SS (1997b) Microbial food webs in marine sediments. II. Seasonal changes in trophic interactions in a sandy tidal flat community. Microb Ecol 34:199-209

Epstein SS, Alexander D, Cosman K, Dompé A and 8 others (1997) Enumeration of sandy sediment bacteria: are the counts quantitative or relative? Mar Ecol Prog Ser 151: $11-16$

Folk RL (1980) Petrology of sedimentary rocks. Hemphill Publishing Co, Austin, TX

Goñi-Urriza M, de Montaudouin X, Guyoneaud R, Bachelet G, de Wit R (1999) Effect of macrofaunal bioturbation on bacterial distribution in marine sandy systems, with special references to sulphur-oxidising bacteria. J Sea Res 41:269-279

Grant J, Schwinghamer P (1987) Size partitioning of microbial and meiobenthic biomass and respiration on Brown's Bank, South-west Nova Scotia. Estuar Coast Shelf Sci 25:647-661

Hagerthey SE, Defew EC, Paterson DM (2002) Influence of Corophium volutator and Hydrobia ulvae on intertidal benthic diatom assemblages under different nutrient and temperature regimes. Mar Ecol Prog Ser 245:47-59

Hancke K, Glud RN (2004) Temperature effects on respiration and photosynthesis in the three diatom-dominated benthic communities. Aquat Microb Ecol 37:265-281

Hansen K, Kristensen E (1997) Impact of macrofaunal recolonization on benthic metabolism and nutrient fluxes in a shallow marine sediment previously overgrown with macroalgal mats. Estuar Coast Shelf Sci 45:613-628

Hayward PJ, Ryland JS (1995) Handbook of the marine fauna of North-West Europe. Oxford University Press, New York

Holme NA, McIntyre AD (1984) Methods for the study of marine benthos, second edition. Blackwell Scientific Publication, London

Isaksen MF, Jørgensen BB (1996) Adaptation of psychrophilic and psychrotrophic sulfate-reducing bacteria to permanently cold marine sediments. Appl Environ Microbiol 62: 408-414

Jahnke RA, Craven DB (1995) Quantifying the role of heterotrophic bacteria in the carbon cycle: a need for respiration rate measurements. Limnol Oceanogr 40(2):436-441

Koroleff F (1969) Direct determination of ammonia in natural waters as indophenol blue. Int Counc Explor Sea 9:1-6

Lorenzen, CJ (1966) A method for the continuous measurement of in vivo chlorophyll concentration. Deep-Sea Res 13:223-227

Lucas F, Meziane T, Bertu G, Retière C (1996) Bacteria of sediment: extraction and distribution in a macrotidal mudflat (Bay of Mont-Saint-Michel). C R Acad Sci Paris, Life Sci 319:537-542

Manini E, Fiordelmondo C, Gambi C, Pusceddu A, Danovaro $\mathrm{R}$ (2003) Benthic microbial loop functioning in coastal lagoons: a comparative approach. Oceanol Acta 26:27-38

Middelburg JJ, Barranguet C, Boschker HTS, Herman PMJ, Moens T, Heip CHR (2000) The fate of intertidal microphytobenthos carbon: an in situ ${ }^{13} \mathrm{C}$-labeling study. Limnol Oceanogr 45(6):1224-1234

Migné A, Davoult D, Spilmont N, Menu D, Boucher G, Gattuso JP, Rybarczyk H (2002) A closed-chamber $\mathrm{CO}_{2}$ flux method for estimating primary production and respiration under emersed conditions. Mar Biol 140(4):865-869
Migné A, Spilmont N, Davoult D (2004) In situ measurements of benthic primary production during emersion: seasonal variations and annual production in the Bay of Somme (eastern English Channel, France). Cont Shelf Res 24: $1437-1449$

Murphy J, Riley JP (1962) A modified single solution method for the determination of phosphate in natural waters. Anal Chim Acta 27:31-36

Parsons TR, Takahashi M, Hargrave B (1984) Biological oceanographic processes 3rd edition. Pergamon Press, London

Perkins RG, Honeywill C, Consalvey M, Austin HA, Tolhurst TJ, Paterson DM (2003) Changes in microphytobenthic chlorophyll a and EPS resulting from sediment compaction due to de-watering: opposing patterns in concentration and content. Cont Shelf Res 23:575-586

Piepenburg D, Blackburn TH, von Dorrien CF, Gutt J and 6 others (1995) Partitioning of benthic community respiration in the Arctic (northwestern Barents Sea). Mar Ecol Prog Ser 118:199-213

Pinckney JL, Carman KR, Lumsden SE, Hymel SN (2003) Microalgal-meiofaunal trophic relationships in muddy intertidal estuarine sediments. Aquat Microb Ecol 31:99-108

Raghukumar C, Loka Bharathi PA, Ansari ZA, Nair S and 6 others (2001) Bacterial standing stock, meiofauna and sediment-nutrient characteristics: indicators of benthic disturbance in the Central Indian Basin. Deep-Sea Res II 48:3381-3399

Rasmussen MB, Henriksen K, Jensen A (1983) Possible causes of temporal fluctuations in primary production of the microphytobenthos in the Danish Wadden Sea. Mar Biol 73:109-114

Riera P, Hubas C (2003) Trophic ecology of nematodes from various microhabitats of the Roscoff Aber Bay (France): importance of stranded macroalgae evidenced through $\delta^{13} \mathrm{C}$ and $\delta^{15} \mathrm{~N}$. Mar Ecol Prog Ser 260:151-159

Riera P, Richard P, Grémare A, Blanchard G (1996) Food source of intertidal nematodes in the Bay of MarennesOléron (France), as determined by dual stable isotopes analysis. Mar Ecol Prog Ser 142:303-309

Rosso L, Lobry JR, Bajard S, Flandrois JP (1995) Convenient model to describe the combined effect of temperature and $\mathrm{pH}$ on microbial growth. Appl Environ Microbiol 61(2):610-616

Rullier F (1959) Etude bionomique de l'Aber de Roscoff. Trav Stat Biol Roscoff 10:1-350

Saburova MA, Polikarpov IG (2003) Diatom activity within soft sediments: behavioural and physiological processes. Mar Ecol Prog Ser 251:115-126

Schwinghamer P, Hargrave B, Peer D, Hawkins CM (1986) Partitioning of production and respiration among size groups of organisms in an intertidal benthic community. Mar Ecol Prog Ser 31:131-142

Spilmont N, Davoult D, Migné A (2006) Benthic primary production during emersion: in situ measurements and potential primary production in the Seine Estuary (English Channel, France). Mar Pollut Bull 53(1-4):49-55

Strickland JDH, Parsons TR (1972) A practical handbook of sea water analysis. Bull Fish Res Board Can, Ottawa

Sundbäck K, Miles A, Göransson E (2000) Nitrogen fluxes, denitrification and the role of microphytobenthos in microtidal shallow-water sediments: an annual study. Mar Ecol Prog Ser 200:59-76

Thamdrup B, Fleischer S (1998) Temperature dependence of oxygen respiration, nitrogen, mineralization, and nitrification in Arctic sediments. Aquat Microb Ecol 15: 191-199 
Thornton DCO, Dong LF, Underwood JC, Nedwell DB (2002) Factors affecting microphytobenthic biomass, species composition and production in the Colne Estuary (UK). Aquat Microb Ecol 27:285-300

Treguer P, Le Corre P (1975) Manuel d'analyse des sels nutritifs dans l'eau de mer, utilisation de l'autoanalyser II Technicon. Laboratoire d'océanographie chimique, UBO Brest

Underwood GJC, Provot L (2000) Determining the environmental preferences of four estuarine epipelic diatom taxa: growth across a range of salinity, nitrate and ammonium conditions. Eur J Phycol 35:173-182

van Es FB (1982) Community metabolism of intertidal flats in the Ems-Dollard Estuary. Mar Biol 66:95-108

Welker ED, Armstrong FA, Richard FA (2002) Microphytobenthos in the Gulf of Trieste (Northern Adriatic Sea): relashionship with labile sedimentary organic matter and nutrients. Estuar Coast Shelf Sci 55(2):259-273

Editorial responsibility: Howard I. Browman (Associate Editor-in-Chief), Storebø, Norway
Wieland A, Kühl M (2000) Irradiance and temperature regulation of oxygenic photosynthesis and $\mathrm{O}_{2}$ consuption in a hypersaline cyanobacterial mat (Solar Lake, Egypt). Mar Biol 137:71-85

Wood ED, Armstrong FA, Richards FA (1967) Determination of nitrate in sea water by cadmium copper reduction to nitrite. J Mar Biol Assoc UK 47:23-31

Yentsch CS, Menzel DW (1963) A method for the determination of phytoplankton chlorophyll and phaeophytin by fluorescence. Deep-Sea Res 10:221-231

Yin K, Harrison PJ (2000) Influence of flood and ebb tides on nutrient fluxes and chlorophyll on an intertidal flat. Mar Ecol Prog Ser 196:75-85

Zweifel UL, Hagström ^ (1995) Total counts of marine bacteria include a large fraction of non-nucleoid containing bacteria (ghosts). Appl Environ Microbiol 61: $2180-2185$

Submitted: June 10, 2005; Accepted: November 22, 2005 Proofs received from author(s): June 12, 2006 